\title{
THE EFFECTIVENESS OF PERFORMANCE MEASUREMENT IN TERMS OF THE CONTEMPORARY BUSINESS ENVIRONMENT
}

\author{
Violeta Domanovic* \\ Faculty of Economics, University of Kragujevac, Kragujevac, Serbia
}

The effective performance measurement systems are inevitably becoming the condition of companies' existence in terms of thecontemporary dynamic and very turbulent environment.The effective performance measurement system enables a company to measure and control its performance in accordance with the defined strategy. In thedesigning of the performance measurement system in the contemporary environment, both financial and non-financial indicators reflecting the effects of the key activitiesadding the value of any company should be respected. The introduction of the diversified strategically aligned performance indicators should improve the organizational outcomes by increasing the quantity of the information relevant for making adecision, which is at the manager's disposal, which makes easierstrategically consistent decisionmaking. The effectiveness of the performance measurement system is influenced by numerous factors, some of which are the subject of the paper research. The aim of the paper is to highlight the significance of the use of multidimensional measures as well as of the specific organizational factors in the process of thecontemporary performance measurement systems implementation.

Keywords: performance measurement, balanced scorecard (BSC), multidimensional performance measures use, organizational factors, performance measurement role

JEL Classification: M21, M41

\section{INTRODUCTION}

In order to survive in terms of thecontemporary dynamic and very turbulent environment, companies must identify their existing positions, clarify their own aims and act in a more effective and more efficient manner. The performance measurement systems make

\footnotetext{
* Correspondence to: V. Domanovic, Faculty of Economics, University of Kragujevac, D. Pucara 3, 34000 Kragujevac, Serbia; e-mail: vterzic@kg.ac.rs
}

all of these possible. Neely et al $(1995,81)$ define the performance measurement system as a "set of metrics that enables the quantification of the efficiency as well as effectiveness of the actions". An effective performance measurement system enables a company to check if the defined aims have been realized and if the company as a whole has made progress (Lebas, 1995), identifying the position, clarifying the aims and highlighting the areas which should be improved, at the same time making the reliable prediction possible (Neely et al, 1996). The effective performance 
measurement system enables a company to measure and control its performances in accordance with the defined strategy.

In designing performance measurement systems in the contemporary environment, both financial and non-financial indicators reflecting the effects of the key activities adding value of the company should be included (Kaplan \& Norton, 1996). The introduction of the indicators aligned with the defined strategy facilitates strategic decision making, which reflects on the final financial results of the company.

Innovations in the performance measurement system mainly point to the role of performance measurement in focusing managers' attention on the long-term consequences of their actions, encouraging them to supervise the implementation of the effective strategy and inform about the evaluation and development of organizational capabilities (Kaplan \& Norton, 1996; Simons, 2000). While some empirical studies point to the fact that the introduction of contemporary measurement systems might result in numerous better final results (Davis \& Albright, 2004; Malina \& Selto, 2001), the results of other studies are unambiguous (Ittner et al, 2003a), and there is a limited insight into how improvements are realized.

Consequently, the paper is going to examine in what relation the use of multidimensional performance measures and the effectiveness of performance measurement systems are. Organizational factors (top management support, training, involvement of employees, connection between performance and rewards) have a significant impact on the effectiveness of the performance measurement implementation.

Performance measurement might have more roles. Grafton et al $(2011,690)$ point to the fact that "the role that enables making decisions refers to the provision of information ex ante to managers in order to remove uncertainties in the decision-making process; conversely, the role that has an impact on decision making refers to the manager's use of information at a higher level in order to evaluate the performances of subordinate managers. The paper stresses the connection between control systems and performances. According the conclusions of the studies of one-dimensional, typical financial performances, information on performance measurement is considered to have an impact on managerial actions by having them included into the evaluation mechanisms (Sprinkle, 2003). Although contemporary performance measurement systems have primarily been designed and adopted to enable strategicallyconsistentdecision making rather than for evaluation (Kaplan \& Norton, 1996), it is evident that information on performance measurement is of remarkable significance in the evaluation processes as well (Ferreira \& Otley, 2009).

Bearing this in mind, the subject of the research would be directed towards the examination of the potential effects of the performance measurement systems on the final performance of a company, and towards potential factors leading to such effects, too. Paper also accentuates the twofold role of performance measurement in the decision-making process. The aim of the paper is to examine the factors that have an impact on the effectiveness of performance measurement and accentuate the connection between the control systems and the final performances of a company. The key hypothesis in the paper is that the effectiveness and efficiency of the performance measurement system depend on the use of multidimensional performance measures and specific organizational factors as well.

In order to test the starting hypothesis, firstly a qualitative methodology based on studying and a descriptive analysis of the research problem would be applied, and the empirical researches of other authors in field of accounting and business economy and management will be used, and by the methods of synthesis and deduction, various attitudes will be synthesized, based on which general conclusions will be derived in relation to the impact of specific organizational factors on the effectiveness of the performance measurement system and in relation to the role of performance measurement in the decisionmaking process as well. Besides, based on the original empirical research conducted by the author, specific conclusions for the Republic of Serbia will be derived.

Starting from the defined subject, aim and hypothesis, firstly, we will present the literature review of the effectiveness of performance measurement systems and the connection between multidimensional performance measures and specific organizational factors and final results; then, we will speak about 
the research methodology in the empirical researches carried out by other authors and in the original author's research, after which relevant conclusions will be derived, indicating possible research limitations and future research directions.

\section{LITERATURE REVIEW}

\section{The effectiveness of performance measurement systems}

The performance measurement systems have been a very interesting research area in the last two decades, and from various aspects: their purpose and usefulness (Simons, 2000), design (Kaplan \& Norton, 1996) and implementation (Speckbacher et al, 2003).

"An effective performance measurement system improves the congruency of employees' aims and organizational aims, enabling managers to evaluate their own performances as well as the performances of employeesin an effective and efficient manner" (Tung et al, 2011, 1289), "has an impact on individual performances through cognitive and motivating mechanisms" (Hall, 2011, 68) and facilitates the formulation of the future strategies and business activities in terms of a more visible environment dynamism (Bisbe \& Malagueño, 2012) and a greater diversification of business activities (Micheli et al, 2011).

The contemporary business environment, as remarkably unpredictable, dynamic, heterogeneous and complex, simply imposes a need to apply financial as well as non-financial performance measures, whichare multidimensional performance measures. Coram et al (2011) examine the extent to which financial analysts rely on non-financial performance indicators and find asymmetric interests for nonfinancial indicators in dependence on the trend of interests for financial information.

The alignment of the strategy, objectives and measures as well as the inclusion of financial and non-financial measures from various perspectivesis the common thing to all contemporary performance measurement systems. However, there are still limited empirical investigations examining the effectiveness of such systems. Najmi et al. $(2012,1124)$ present "a conceptual model for the revision of the performance measurement systems designed on the basis of the performance prism, in a way that the presented model categorizes the revision process and tools into two main categories: the business performances revision and the performance measurement systems revision". Moreover, the majority of studies evaluate the effectiveness of such systems in relation to the total organizational performances (Crabtree \& DeBusk, 2008; Davis \& Albright, 2004; Ittner et al, 2003b), supposing a direct link between performance measurement systems and total corporate performances. The final performances, however, such as an increase in net sales, a return on capital and a return on equity would not be realized if the specific aims were not realized (for instance, an increase in the sales revenue, cost reduction, the motivation of employees, feedback and a precise evaluation of business units performances).

The effectiveness of the performance measurement systems implementation depends on numerous factors (Tung et al, 2011). The first one is related to the use of multidimensional performance measures that could remove the limitations of the traditional performance measurement systems and increase the effectiveness of the same as well (Van der Stede et al, 2006; Kaplan \& Norton, 1996). Although the use of multidimensional performance measures has widely been adopted in the literature, which has resulted in numerous multidimensional models (Van der Stede et al, 2006), there is a significant variation with respect to the extent to which the most prominent multidimensional approach, the BSC, has been adoptedin the USA, the German-speaking countries, the Nordic countries and Serbia (Domanović, 2010, 306-310), which makes the link between such measures and the mere effectiveness of performance measurement systems suspicious.

The effectiveness of performance measurement systems from the various aspects has been the subject of interest of many authors in recent times. Thus, Grafton et al (2010) examine the role of performance measurement and evaluation in the process of the building of organizational capabilities and performances. Pavlov \& Bourne (2011) analyzed the effects of performance measurement on performances based on 
organizational routines as analytical instruments in order to connect various factors, which have an impact on performance measurement effectiveness, into one coherent explanatory model. "Organizational routines are actually organizational processes which lead to organizational performances and are conceptualized at two levels - an abstract ideaof routine and its expression into a specific action" (Pavlov \& Bourne, 2011, 112). Lee \& Yang $(2011,84)$ examined "the effect of the organization structure and competition on the performance measurement design as well as the effect of their common influence on performances, stressing that the performance measurement design has two dimensions: the use of integrated performance measures in relation to the four perspectives of the BSC and the phases of the performance measurement systems development". The conclusions partly point to the common effects on performances. Specifically, the mere extent of the competition, there would be the more significant positive correlation between the phase of the performance measurement systems development and performances and the use of integrated measures impact the organizational performances more in the mechanistic organizations than in organic ones. Franco-Santos et al (2012) analyzed the consequences of the use of contemporary performance measurement systems in detail into three categories: employees' behavior, organizational capabilities and performances. In the category of the consequences on employees behavior, they highlight: a strategic focus, cooperation, coordination and participation, motivation, role understanding and job satisfaction, decision making, learning and selfcontrol, leadership and culture, prejudices about subjectivity, conflicts and tensions; in the category of consequences on the organizational capabilities, they stress strategic processes, communication and corporate control; in the category of the consequences on total performances, they point to performance at the business unit level, the team, managers and the whole of the supply chain. "Performance measurement might stimulate the initiatives of employees to improve operating performances, especially when employees participate in the performance measures development" (Groen et al, 2012, 120). Artz et al (2012) examine the role of the performance measures properties in the process of performance measurement systems designing and making strategic decisions at the business unit level.

\section{The connection between multidimensional performance measures and performance measurement systems effectiveness}

Multidimensional performance measurement systems improve the consideration of all relevant performance dimensions (Ittner et al, 2003b). Van der Stede et al (2006) found that organizationswhich, regardless of the strategy, have extensive performance measurement systems, which include objective and subjective nonfinancial measures, have greater comprehensive performances. Van der Stede et al (2006) also demonstrated that non-financial performance measures are better than the financial ones with respect to the new initiatives implementation and management. The numerous pieces of the literature prove that the implementation of multidimensional systems contributes to the effectiveness of the same (Tung et al, 2011; Crabtree \& DeBusk, 2008; Davis \& Albright, 2004; Ittner et al, 2003b; Malina \& Selto, 2001). Most of these studies examined the effectiveness of such systems from the perspectives of their contribution to financial performances. For instance, Domanović (2010) examines the corporate performance measurement from different branches in order to fortify the relationship between the BSC and financial performances. This study supports the theory that the BSC could be used in order to improve financialperformances. Crabtree \& DeBusk (2008) found that theBSC is also connected with higher stock returns. Malina \& Selto (2001) concluded that the BSC is an effective framework for a corporate strategy evaluation. Their results point to the causal relations between motivation, strategic alignment and effective management control with the BSC.

\section{The connection between organizational factors and performance measurement systems effectiveness}

The most prominent organizational factors with an impact on performance measurement systems effectiveness are the top management support (Bourne et al, 2002), training, employees participation and a link between performances and rewards (Burney et al, 2009).

The top management support is a significant contingent factor supportive of different innovations. The influence of the top management on performance 
measurement systems effectiveness was analyzed (Tung et al, 2011; Bourne et al, 2002; Kennerley \& Neely, 2002), accentuating that the top management support is critical for the design and implementation of the performance measurement system.

Cavaluzzo \& Ittner $(2004,249)$ point out that "performance measurement systems effectiveness directly depends on the extent of managers' training". All performance measures should be communicated clearly and should be relevant and reliable so that managers could receive useful information for making decisions, and employees' better understanding, which would reflect on the greater commitment and efficiency.

A greater participation of employees in the process of designing and implementing performance measurement systems directly contributes to their effectiveness (Kaplan \& Norton, 2001) because of the cognitive mechanismssuch as better communication, knowledge application, job understanding, on the one hand, and the motivating mechanismssuch as less resistance to change, commitment to the performance measurement system, the acceptance of feedback and aims (Hall, 2011), on the other.

The link between performances and rewards is a vital contingent factor in motivating employees and is considered as a crucial factor of systems effectiveness (Burney et al, 2009).

\section{The performance measurement role in the process of making decisions}

Performance measurement information facilitates the decision-making process, the identification of the problem and suggesting corrective measures; gives a signal on critical processes, improves organizational learning and enables the plans and strategy revision as well (Grafton et al, 2010; Kaplan \& Norton, 1996; Simons, 2000). Performance measures might be used for feedback and feed-forward as well as for a diagnostic and interactive control (Widener, 2007). In the paper, the use of performance measures in the feedback/feed-forward dichotomy is conceptualized. However, the adoption of the feedback/feed-forward distinction enables managers of organizational units to focus their attention on the distinctive use of performance measures in the process of making individual decisions. Tessier \& Otley (2012) analyze the positive and negative control dimensions and the result they give the revised model, which explicitly makes a distinction between managers' attention and employees' perceptions of control.

Feedback and feed-forward performance measures are part of cybernetic control (Grafton et al, 2010, 692). The primary difference between them is that feedback control is focused on the evaluation of real outcomes, and feed-forward control is focused on the prediction of future outcomes. "The use of performance information as a feedback mechanism providesmanagers with information of the outcomes that do not fulfill the expectations and acts as a catalyst of the problem identification" (Grafton et al, 2010, 692). This stimulates problem solving, the identification of the corrective action and organizational learning in the domain of the existing activity (Ferreira \& Otley, 2009) as well as managers' focusing on the realization of the current aims (Nørreklit, 2000; Simons, 2000). Nørreklit $(2000,81)$ accentuates the fact that "the control process should be more interactive in the strategy formulation, making the BSC and in the process of the BSC implementation". The use of performance measures as a way of signalizing future outcomes, communicating the strategy to employees and being a catalyst of planning and aims setting increases future performances (Kaplan \& Norton, 1996).

The management control systems balance enables the creation of dynamic tensions and unique organizational capabilities, so that the interactive control lever has a significant role (Mundy, 2010). Gond et al (2012) analyze the influence of the management control system on the integration of sustainability in the framework of the organizational strategy basedon Simon's control levers.

\section{RESEARCH METHOD}

The paper relies on the empirical analysis of the relation between the specific organizational factors (top management support, training, employees participation and a link between performances and rewards) and 
performance measurement systems effectiveness (Tung et al, 2011), the examination of the performance measurement effects on performances (Pavlov \& Bourne, 2011), the review of the potential effects of the contemporary performance measurement systems on employees' behavior, the organizational capabilities and performances of the business units, teams and managers (Franco-Santos et al, 2012), the empirical analysis of the performance measurement role and evaluation in building up organizational capabilities and performances (Grafton et al, 2010), as well as the original author's empirical research conducted in 2009, while writing the doctoral dissertation (Domanović, 2010). The subject of the author's research was, among other things, the role of the balanced scorecard in the process of corporate efficiency improvement, generally, with a special view of the possibilities and effects of the BSC implementation in companies in Serbia, if the author supposed that managers were partly or in detail acquainted with the BSC concept and had partly or thoroughly implemented it in the process of the corporate efficiency evaluation. The starting hypothesis was that the BSC implementation was in the positive correlation with the corporate efficiency improvement.

In the empirical research of the other authors, whose research subject has already been explained (Tung et al, 2011; Franco-Santos et al, 2012; Grafton et al, 2010), the technique of the survey of financial managers was applied on a random sample of productive and service organizations in Australia, while in the author's original research, the questionnaire technique and interview with financial managers and control managers in reputable selected companies in Serbia were also applied. Senior financial managers and control managers were selected because it was believed that they would have a better understanding of performance measurement systems. As to the influence of the organizational factors on performance measurement systems effectiveness based on the research carried out by the already mentioned authors, the responsiveness rate is 30.9\% (Tung et al, 2011, 1294). As to the performance measurement role, 794 respondents of the business unit managers were identified, 188 questionnaires were filled out and sent back (the responsiveness rate being $24.58 \%$ is), and
183 were completely filled out; the respondents had been working for the current employer for 12 years on average (median $=10$ years), and had an average 7.48-year-long experience (median $=5$ years) in the current strategic business units (SBU) and had been in the position of a manager for 4,17 years (median $=3$ years); the respondents were of an average 40-49 years of age (Grafton et al, 2010, 695). In the author's original research, six questionnaires were directly collected from and filled out by the managers of reputable companies, and one questionnaire was uncompleted (Domanović, 2010, 268).

\section{Variable measurement}

The system effectiveness was measured depending on the level at which the desired outcomes of the performance measurement systems had been realized. Tung et al (2011, 1294-1296) asked the respondents "to evaluate the level at which their performance measurement system realized each of the desired outcomesaccording to Likert's 5-level scale, starting from 1 "not at all" to 5 "to a great extent", so they divided the outcomes into two dimensions: those referring to the achievement of the organizational aims and objectives, thus marking this dimension as 'outcomes related to performances', on the one hand, and those referring to employees, thus marking this dimension as 'outcomes related to employees'. The performance outcomes include: motivating performances, providing help in the aim realization, the development of the performance-oriented culture, change support, the supply of useful feedback on performances, the strategy implementation, a precise business evaluation, employees' commitment to the defined aims and the alignment of the individual performances with the business units' performances, while the outcomes connected with employees include: individual skills and knowledge development, the identification of talented employees, talented employees rewards, the identification of poor performance employees, poor performance employees management (Tung et al, 2011, 1294-1295). An average score by all these items was calculated, so that greater (lesser) scores represented the better (worse) effectiveness of the performance measurement system. 
In order to evaluate the extent to which the multidimensional measures were used, two approaches were applied: firstly, the respondents had to simply mark if they had implementedthe BSC ("yes" or "no") and secondly, a more comprehensive approach focused on the performance measures adopted in the organization, demanding that the respondents should mark the extent to which they had used different measures from different BSC perspectives (Tung et al, 2011, 1295). These measures had been derived from the BSC literature and were largely designed for production organizations (Van der Stede et al, 2006; Ittner et al, 2003b; Kaplan \& Norton, 1996). "The average 0.6-point factor analysis revealed 26 items in 6 specific dimensions, covering the following dimensions: finance, internal business processes, learning and growth and sustainability" (Tung et al, 2011, 1295). Performance measures from the finance perspective include: sales revenue, a return on investment, an improvement of the net assets/liabilities improvement. From the customer perspective, the measures are: product delivery on time, the number of new customers, product quality, and the number of returned products. From the perspective of internal business processes, the measures are: resource consumption, productivity, a work cycle, and warranty right costs. From the learning and growth perspective, the measures are: training hours, an improvement of employees' capacity, the number of implemented suggestions made by employees, the number of new products, the time of the commercialization of new products, the percentage of new product revenue. From the perspective of sustainability, the measures are: investments in environment management, investments in the local community, services connected with the local community. Each of these five perspectives is scored as a sum of particular items in each perspective, where greater (lesser) scores that pointed to the fact that the performance measurement system is focused on each perspectiveto a greater (lesser) extent, and an average score is calculated as a sum of the average score in each perspective, thus a greater (lesser) score means that the multidimensional measures are used to a greater (lesser) extent (Tung et al, 2011, 1295).

Organizational factors, which are relevant for the effectiveness of the performance measurement system, are: the top management support, training, employee participation, a link between performances and rewards. Each of these four organizational factors was measured by the summarized Likert's scale of 5 points, starting from 1 "and do not agree at all" to 5 "strongly agree" (Tung et al, 2011, 1295), so that "the top management support was measured by the summarized scale, based on the respondents' statement about how much the top management supplied the adequate resources, efficiently communicated with the employees and by its authority provided support to the performance measurement system" (Tung et al, 2011, 1295). The top management support was measured as an average score, so a greater (lesser) score points to a greater (lesser) top management support. Specifically, the respondents had to evaluate if the employees had been trained to develop, implement and understand the performance measurement systems at an adequate level, so training was also measured as an average score, where a greater (less) score points to a greater (lesser) training level. Besides, there was an examination of the extent to which the respondents took part in designing the performance measurement system and in the mere selection of performance measures, so the final score represents the average scores of particular items, and a greater (lesser) score means greater (lesser) employees' participation (Tung et al, 2011, 1296). In order to analyze the effectiveness of the performance measurement system, it is important to examine how much the contemporary performance measurement system stimulates employees to be more efficient in their jobs, that isthe extent to which performances are connected with financial rewards such as payments or bonuses as well as non-financial rewards such as recognition or service rewards.

In the author's original empirical research, the respondents had to state if they were acquainted with the contemporary performance measurement system, if they had implemented some contemporary model or were still implementing the traditional one, what the specific effects of the contemporary model implementation on the final corporate performances and the performances of the strategic business units and individuals were (Domanović, 2010, 323-326). The author offered several potential answers and the respondents were supposed to circle all they found relevant to them, although there were questions where they were supposed to add something not offered 
in the survey. Based on the respondents' replies, descriptive statistics were made, which gave a real insight into the effects and possibilities of the BSC implementation in Serbia.

\section{The usage of the performance measurement information}

The feedback and feed-forward application of the performance measurement information, Grafton et al $(2010,697)$, was measured via the eight issues based on the existing literature (Ittner et al, 2003a; Kaplan \& Norton, 1996; Simons, 2000; Sprinkle, 2003). The respondents (both in the author's original empirical research and in the research of the mentioned authors) were supposed to rank the extent to which they actually used the measures which facilitateddecision making: "(a) setting the performance targets for the business units and/or employees at the business unit level; (b) the guidance for the strategy implementation; (c) the organizational learning promotion; (d) the analysis of the past decisions' effects; (e) the prompt re-examination of the strategy and the meta values; (f) action plans development; (g) the communication of the significant aspects of the business units strategy; (h) the identification of the necessity for corrective actions" (Domanović, 2010, 323-326; Grafton et al, 2010, 697). Items $a, b, f$ and $g$ were marked as the feedforward control, while the others were marked as the feedback control.

\section{Performance}

In order to gain an insight into the business unit performances, the respondents had to evaluate the performances during the last year in relation to the competitors (where $1=20 \%$ better than competitors, $7=20 \%$ worse than competitors); and the total business units performances in relation to the expectations (where 1 = bad, 7 = remarkably) (Grafton et al, 2010, 697). "The factor analysis of the two items reveals one factor that could be marked as "performance" (PERF) and this concept includes $67 \%$ of the explained variations and Cronbach's Alpha is 0.52; so, it was found that PERF was in the significant correlation $(r=0.276$, $\mathrm{p}<0.01$ ) with the measure consisting of the respondents' performances in comparison with the competitors with respect to: (a) the market share; (b) the profit; (c) the rate of the sales revenue, which demonstrated the validity criteria" (Grafton et al, 2010, 697-698).

\section{RESULTS}

Table 1 accounts for the summary descriptive statistics for dependent and independent variables.

An average score of the performance measurement system effectiveness for the performance outcomes was and for the staff outcomeswas something higher than the midpoint of the interval, which shows that the respondents evaluated their performance measurement systems as moderately effective. The outcomes related to the performances were realized to a greater extent, with the mean score of all the items being equal or higher than the outcomes related to the staff. The outcomes related to the performances and those realized to the greatest extent were: providing help in the aim realization; feedback information about the employees' performances; the development of a performance-oriented cultureand an accurate evaluation of the business units performances. The outcomes related to the staff and those realized at the highest level included: the development of individual skills and knowledge, the identification of talented employeesand rewarding talented employees. As to the organizational factors, the mean value of the linkage between performances and non-financial rewardswas below the midpoint of the interval and points to a relatively weak connection between performances and non-financial rewards.

As to the usage of the multidimensional performance measures, the research (Tung et al, 2011, 1297) also showed that 39 respondents (33.1\%) stated that they applied the BSC in their business units. A more comprehensive approach to the measurement of the multidimensional performance measures use was focused on the extent to which the 26 performance measures from the five BSC perspectives were implemented. The mean value of the multidimensional measures use is below the midpoint of the interval, which points to the moderate use of the multidimensional measures in production organizations. 
Table 1 Descriptive statistics

\begin{tabular}{|c|c|c|c|c|c|c|}
\hline Variables & $\begin{array}{l}\text { Number of } \\
\text { respondents }\end{array}$ & Mean & $\begin{array}{l}\text { Standard } \\
\text { deviation }\end{array}$ & $\begin{array}{c}\text { Minimum } \\
\text { (theoretically) }\end{array}$ & $\begin{array}{c}\text { Maximum } \\
\text { (theoretically) }\end{array}$ & $\begin{array}{c}\text { Cronbach } \\
\alpha\end{array}$ \\
\hline \multicolumn{7}{|l|}{ Independent } \\
\hline $\begin{array}{l}\text { Multidimensional performance } \\
\text { measures use }\end{array}$ & 118 & 2.94 & 0.70 & $1.17(1)$ & $4.67(5)$ & \\
\hline Top management support & 117 & 3.51 & 1.02 & $1(1)$ & $5(5)$ & 0.915 \\
\hline Training & 117 & 3.11 & 1.07 & $1(1)$ & $5(5)$ & 0.963 \\
\hline Employees participation & 117 & 2.41 & 1.02 & $1(1)$ & $5(5)$ & 0.761 \\
\hline $\begin{array}{l}\text { Link between performances and } \\
\text { financial rewards }\end{array}$ & 117 & 3.50 & 1.16 & $1.00(1)$ & $5.00(5)$ & \\
\hline $\begin{array}{l}\text { Link between performances and } \\
\text { non-financial rewards }\end{array}$ & 117 & 2.93 & 1.13 & $1.00(1)$ & $5.00(5)$ & \\
\hline \multicolumn{7}{|l|}{ Dependent variables } \\
\hline $\begin{array}{l}\text { Performance measurement systems } \\
\text { effectiveness (performance out- } \\
\text { comes) }\end{array}$ & 117 & 3.50 & 0.81 & $1(1)$ & $5(5)$ & 0.932 \\
\hline $\begin{array}{l}\text { Effectiveness of the system (staff } \\
\text { outcomes) }\end{array}$ & 117 & 3.26 & 0.93 & $1(1)$ & $5(5)$ & 0.924 \\
\hline
\end{tabular}

Source: Tung et al, 2011, 1296

As it can be seen from Table 2, the biggest accent was on the financial perspective (3.59), then on customers (3.43), learning and growth (3.11) and internal business processes (3.06). The sustainability mean (2.19) was below the midpoint of the interval, which points to the weak application of this perspective.

As to the Republic of Serbia (Domanović, 2010), the managers were mainly not acquainted with the BSC or were partly acquainted with it. Truly, some managers

Table 2 Multidimensional performance measures use

\begin{tabular}{lcc}
\hline BSC perspectives & Mean & Rank \\
\hline Finance & 3.59 & 1 \\
Customers & 3.43 & 2 \\
Internal business pro- & 3.06 & 3 \\
cesses & 3.11 & 4 \\
Learning and growth & 2.19 & 5 \\
Sustainability & \\
\hline
\end{tabular}

Source: Author, based on Tung et al, 2011, 1297 did apply the BSC, but were not conscious of what the BSC was. The biggest accent was still on (Table 3) finance, then on customers, learning and growth and internal business processes.

The results of the research the author had conducted showed that managers of many companies in the world were skeptic with respect to the final effects of the BSC implementation on corporate efficiency. Corporate managers in the German-speaking countries

Table 3 Multidimensional performance measures use in the Republic of Serbia

\begin{tabular}{lc}
\hline BSC perspectives & Number of companies \\
\hline Finance & 5 \\
Customers & 5 \\
Internal business processes & 3 \\
Learning and growth & 4 \\
Others & 1 \\
\hline
\end{tabular}

Source: Author 
considered the BSC as an instrument of the shareholder value management. The BSC is present a lot in the Nordic countries, contributing mostly to the logistic, delivery reliability and warehousing, as well as to nonfinancial efficiency indicators. In Serbia, a consistent implementation of the BSC is characteristic for companies with foreign capital. The economic effects of the BSC implementation were: a more systematic analysis of the efficiency parameters, costs comparison and a more efficient realization of the business strategy, and at the individual level, the BSC helps in having jobs done, points to certain shortcomings of the processes and employee dissatisfaction, and enables undertaking corrective measures. Also, the variable payment of employees, primarily managers, partly depends on the plan realization, i.e. on the target parameters value in the BSC.

\section{Analysis of the multidimensional measures use and organizational factors on performance measurement systems effectiveness}

Table 4 displays the results of the one-way variation analysis (ANOVA), which examined the difference in performance measurement effectivenessdepending on whetherthe respondents applied the BSC or not, showing that the respondents who applied the BSC had reached a more significant effectiveness level both with respect to the performance outcomes and the staff outcomes.

These results provided us with a preliminary proof that the use of multidimensional performance measures was connected to performance measurement effectiveness, which confirms the starting hypothesis. The connection between multidimensional measures and effectiveness was also analyzed by a more comprehensive approach on the basis of the extent to which the multidimensional measures were used. A step-by-step regression is applied in order to examine the connection between the use of the multidimensional performance measures use and organizational factors and the system effectiveness, based on the replies provided by the 115 respondents (Table 5).

The results accounted for in Table 5 show that, with respect to the outcomes related to the performances, the model was very statistically significant (F 1/4 63.812, p 1/4 0.000), with the coefficient of determination 0.530 , pointing to the factthat $53 \%$ of the variation in the performance outcomes could be explained by explanatory factors. This model revealed that the use of multidimensional performance measures $\left(p^{1 / 4} 0.000\right)$ was significantly connected with the system effectiveness.

Besides, the top management support ( $\left.p^{1 / 4} 0.000\right)$ was significantly connected with the outcomes connected with the performances. As to the outcomes connected to the staff, with the coefficient of determination 0.405 , which points to the fact that $40.5 \%$ of the variation in the realization of the outcomes connected to the staff, could be explained by the explanatory factors.

Thus, the use of multidimensional performance measures is significantly connected to the realization of the staff outcomes and the training level wasalso significantly connected to the performance measurement effectiveness. These findings give a further support to the starting hypothesis. The significance of the use of the multidimensional performance measures in explaining the level of the

Table 4 Results of the one-way variation analysis (ANOVA)

\begin{tabular}{lccccccc}
\hline \multirow{2}{*}{$\begin{array}{l}\text { Implementation } \\
\text { BSC }\end{array}$} & $\begin{array}{c}\text { Number of } \\
\text { respondents }\end{array}$ & Mean & F statistics & $\begin{array}{c}\text { Signifi- } \\
\text { cance }\end{array}$ & Mean & F statistics & $\begin{array}{c}\text { Signifi- } \\
\text { cance }\end{array}$ \\
\hline Non-users & 39 & 3.88 & 14.297 & 0.000 & 3.71 & 15.869 & 0.000 \\
Nekorisnici & 78 & 3.31 & & & 3.03 & & \\
\hline
\end{tabular}


Table 5 Results of the gradual regression analysis

\begin{tabular}{lcccccc}
\hline \multirow{2}{*}{ Variables } & \multicolumn{3}{c}{ Performance outcomes } & \multicolumn{3}{c}{ Staff outcomes } \\
\cline { 2 - 7 } & Coefficient & t statistics & Significance & Coefficient & t statistics & Significance \\
\hline Multidimensional systems & 0.343 & 4.512 & 0.000 & 0.374 & 4.465 & 0.000 \\
Top management support & 0.487 & 6.411 & 0.000 & & & \\
Training & & & & 0.362 & 4.325 & 0.000 \\
Fvalue & 63.812 & & 38.535 & & \\
P value & 0.000 & & 0.000 & & \\
Coefficient of determina- & 0.530 & & 0.405 & & \\
tion & & & & & \\
Adjusted coefficient of & 0.522 & & 0.395 & & \\
determination & 115 & & 115 & & \\
Number of respondents & & & &
\end{tabular}

Source: Author, based on Tung et al, 2011, 1298

effectiveness of the performance measurement systems imposed a further explanatory analysis in order to examine the connection between the BSC perspectives and the system effectiveness.

\section{Analysis of the connection between the BSC perspectives and performance measurement system effectiveness}

The gradualregression analysis has produced caused thefindings that the outcomes connected to the performances are statistically significant, with the coefficient of determination 0.528 , which points to the fact that $52.8 \%$ of the variations in the realization of the outcomes connected to the performances could be explained by the two perspectives of the BSC, significantly connected to the outcomes connected to the performances: internal business processes and learning and growth. The outcomes connected to the staff are statistically significant, with the coefficient of determination 0.499 , which means that $49.9 \%$ of the variations in the realization of the outcomes connected to the staff could be explained by the two BSC perspectives, which have significantly been connected to the outcomes connected to the staff: learning and growth, and sustainability.

In Serbia, the outcomes referring to the performances could significantly be explained by the financial perspective and the customer perspective $(100 \%)$, whereas the outcomes referring to the employees could be explained by the internal business process perspective $(60 \%)$ and the learning and growth perspective $(80 \%)$.

\section{CONCLUSIONS}

Performance measurement systems effectiveness could be observed through the two dimensions, namely outcomes connected to corporate performances and outcomes connected to staff. The factor analysis revealed that the midpoint of both dimensions was above the midpoint of the interval, which means that the system effectiveness is at a moderate level. Such a conclusion highlights the significance of the examination of the contingent factors having an influence on the system effectiveness. The results also showed that a bigger success was realized in the performance-oriented outcomes than in the stafforiented ones. This means that the performance measurement systems should mainly be used as a management tool to motivate, implement a strategy and realize aims, i.e. as aninstrument of strategic control and management control, too.

The realization of the outcomes connected to the staff such as concern for employees, the efficient usage 
of time, and management by poor-performance employees was less highlighted. The final conclusion refers to the mere existence of a company in a changeable environment, which depends on both outcomes. Hence, the organizations that look at the employees as potential partners and significant assets increase a possibility to achieve better organizational performances. Also, there is evidence that staff outcomes could be of help during the performance outcomes realization. If organizations were devoted to employees' concerns in the right way, they would be more emotively connected to the organization and, hence, be more willing to realize the organizational aims.

The more comprehensive analysis of the use of multidimensional performance measures revealed that production companies put the biggest emphasis on the measures referring to the finance perspective of the BSC, then on customers, learning and growth, internal business processes and sustainability.

The analysis of the relationship between the use of multidimensional performance measures and organizational factors and effectiveness revealed that the use of these measures, as operationalized in the BSC, together with organizational factors (the top management support and training) is significantly connected with effectiveness.

The analysis of the relationship between the organizational factors and the system effectiveness gains an insight into the prevailing organizational conditions that could increase/impel effectiveness. The top management support is connected with the performance outcomes, and the training level with the staff outcomes. Hence, in order to realize desired performance outcomes, the top management should make a concentrated effort directed towardsa continual improvement, an open communication and a consistent support as well. Hence, the top management was encouraged to be personally devoted to the performance measurement systems and to ensure that enough time and resources were devoted to a meaningful development and management by the existing systems. Besides, organizations providing better staff training could realize desired staff outcomes. The two dimensions of the system effectiveness, the performance and staff outcomes, enable the management to be conscious of a need to focus on the different aspects of the system effectiveness and provide researchers with a new measure for the evaluation of effectiveness as well. Besides, the connection of multidimensional performance measures and organizational factors with the system effectiveness enables managers to have an insight into the desired characteristics of the effective system and the prevailing organizational conditions supporting the systems. Hence, managers should focus on the use of multidimensional measures and increase the top management support and training in relation to the performance measurement systems.

This research is subject to the usual limitations of the survey and data collection from secondary sources. Since the survey is useful in the process of the determination of the connections, not causal relations, among variables, this kind of approach generates potential threats connected with the respondents' replies. This is also valuable for the author's research, beside the fact that the sample size was too small and insufficient for a more serious statistical analysis. In the future, the sample size should be increased and the connection of other organizational factors such as, for instance, the organizational structure, the management style and human relations with the system effectiveness should be taken into consideration. In order to increase the generality of the conclusions, future studies could be implemented using similar parameters in other activities such as the services and non-profit sectors.

In the future, the ways in which performance measurement impacts decision making could further be researched, especially in such cases where the roles are potentially in conflict, instead of mutually strengthening each other. It would be interesting to examine the extent to whichan interaction amongst the roles of performance measurement is more or less focused on financial measures, and how these interactions reflect on specific individual decisions.

\section{ACKNOWLEDGMENTS}

This paper is a part of the interdisciplinary research Project (No. 41010), which is funded by the Ministry of Sciences of the Republic of Serbia. 


\section{REFERENCES}

Adler, R. (2011). Performance management and organizational strategy: how to design systems that meet the needs of confrontation strategy firms. The British Accounting Review, $43,251-263$.

Artz, M., Homburg, C., \& Rajab, T. (2012). Performancemeasurement system design and functional strategic decision influence: the role of performance-measure properties. Accounting, Organizations and Society, 37, 445-460.

Baird, K., Harrison, G., \& Reeve, R. (2007). Success of activity management practices: the influence of organizational and cultural factors. Accounting and Finance, 47(1), 47-67.

Bisbe, J., \& Malagueño, R. (2012). Using strategic performance measurement systems for strategy formulation: does it work in dynamic environments? Management Accounting Research, 23, 296-311.

Bourne, M. C., Neely, A. D., Platts, K. W., \& Mills, J. F. (2002). The success and failure of performance measurement initiatives: the perceptions of participating managers. International Journal of Operations and Production Management, 22(11), 1288-1310.

Burney, L. L., Henle, C. A., \& Widener, S. K. (2009). A path model examining the relations among strategic performance measurement system characteristics, organizational justice, and extra- and in-role performance. Accounting, Organizations and Society, 34(3/4), 305-321.

Cavaluzzo, S. K., \& Ittner, C. D. (2004). Implementing performance measurement innovations: evidence from government. Accounting, Organisations and Society, 29(1), 243267.

Chenhall, R. H. (2003). Management control systems design within its organizational context: findings from contingency-based research and directions for the future. Accounting, Organizations and Society, 28(2/3), 141-163.

Coram, J. P., Mock, J. T., \& Monroe, S. G. (2011). Financial analysts' evaluation of enhanced disclosure of non-financial performance indicators. The British Accounting Review, 43, 87101.

Crabtree, A. D., \& DeBusk, G. K. (2008). The effects of adopting the balanced scorecard on shareholder returns. Advances in Accounting, 24(1), 8-15.

Davis, S., \& Albright, T. (2004). An investigation of the effect of balanced scorecard implementation on financial performance. Management Accounting Research, 15(2), 135153.

Domanović, V. (2010). Balanced Scorecard - mogućnosti $i$ efekti primene. Kragujevac: Ekonomski fakultet Univerziteta $\mathrm{u}$ Kragujevcu.
Ferreira, A., \& Otley, D. (2009). The design and use of performance management systems: An extended framework for analysis. Management Accounting Research, 20(4), 263-282.

Franco-Santos, M., Lucianetti, L., \& Bourne, M. (2012). Contemporary performance measurement systems: a review of their consequences and a framework for research. Management Accounting Research, 23, 79-119.

Gond, J.-P., Grubnic, S., Herzig, C., \& Moon, J. (2012). Configuring management control systems: theorizing the integration of strategy and sustainability. Management Accounting Research, 23, 205-223.

Grafton, J., Lillis, M. A., \& Widener, K. S. (2010). The role of performance measurement and evaluation in building organizational capabilities and performance. Accounting, Organizations and Society, 35, 689-706.

Groen, B. A. C., Wouters, M. J. F., \& Wilderom, C. P. M. (2012). Why do employees take more initiatives to improve their performance after co-developing performance measures? A Field study. Management Accounting Research, 23, 120-141.

Hall, M. (2011). Do comprehensive performance measurement systems help or hinder managers' mental model development? Management Accounting Research, 22, 68-83.

Ittner, C. D., Larcker, D. F., \& Randall, T. (2003a). Performance implications of strategic performance measurement in financial services firms. Accounting, Organizations and Society, 28(7/8), 715-41.

Ittner, C. D., Larcker, D. F., \& Meyer, M. W. (2003b). Subjectivity and the weighting of performance measures: evidence from a balanced scorecard. The Accounting Reivew, 78(3), 725-758.

Kaplan, R. S., \& Norton, D. P. (1996). Linking the balanced scorecard to strategy. California Management Review, 39(1), 53-79.

Kaplan, R. S., \& Norton, D. P. (2001). The Strategy-focused Organization: How Balanced Scorecard Companies Thrive in the New Business Environment. Boston: Harvard Business School Press.

Kennerley, M., \& Neely, A. (2002). A framework of the factors affecting the evolution of performance measurement systems. International Journal of Operations and Production Management, 22(11), 1222-1245.

Lebas, M. J. (1995). Performance measurement and performance management. International Journal of Production Economics, 41(1-3), 23-35.

Lee, C.-L., \& Yang, H.-J. (2011). Organization structure, competition and performance measurement systems and their joint effects on performance. Management Accounting Research, 22, 84-104. 
Malina, M. A., \& Selto, F. H. (2001). Communicating and controlling strategy: an empirical study of the effectiveness of the balanced scorecard. Journal of Management Accounting Research, 13, 47-90.

Micheli, P., Mura, M., \& Agliati, M. (2011). Exploring the roles of performance measurement systems in strategy implementation: the case of a highly diversified group of firms. International Journal of Operations \& Production Management, 31(10), 1115-1139.

Mundy, J. (2010). Creating dynamic tensions through a balanced use of management control systems. Accounting, Organizations and Soceity, 35, 499-523.

Najmi, M., Etebari, M., \& Emami, S. (2012). A framework to review performance prism. International Journal of Operations \& Production Management, 32(10), 1124-1146.

Neely, A. (1999). The performance measurement revolution: why now and what next? International Journal of Operations and Production Management, 19(2), 205-228.

Neely, A., Gregory, M., \& Platts, K. (1995). Performance measurement system design: a literature review and research agenda. International Journal of Operations and Production Management, 25(12), 80-116.

Neely, A., Mills, J., Platts, K., Gregory, M., \& Richards, H. (1996). Performance measurement system design: should process based approaches be adopted? International Journal of Production Economics, 46, 423-431.

Nørreklit, H. (2000). The balance on the balanced scorecard a critical analysis of some of its assumptions. Management Accounting Research, 11(1), 65-88.
Pavlov, A., \& Bourne, M. (2011). Explaining the effects of performance measurement on performance - an organizational routines perspectives. International Journal of Operations \& Production Management, 31(1), 101-122.

Simons, R. (2000). Performance Measurement and Control Systems for Implementing Strategy. NJ: Prentice-Hall, Englewood Cliffs.

Speckbacher, G., Bischof, J., \& Pfeiffer, T. (2003). A descriptive analysis on the implementation of balanced scorecard in German speaking countries. Management Accounting Research, 14(4), 361-388.

Sprinkle, G. B. (2003). Perspectives on experimental research in managerial accounting. Accounting, Organizations and Society, 28(2-3), 287-318.

Tessier, S., \& Otley, D. (2012). A conceptual development of Simons' levers of control framework. Management Accounting Research, 23, 171-185.

Tung, A., Baird, K., \& Schoch, P. H. (2011). Factors influencing the effectiveness of performance measurement systems. International Journal of Operations \& Production Management, 31(12), 1287-1310.

Van der Stede, W. A., Chow, C. W., \& Lin, T. W. (2006). Strategy, choice of performance measures, and performance. Behavioral Research in Accounting, 18, 185-205.

Widener, S. K. (2007). An empirical analysis of the levers of control framework. Accounting, Organizations and Society, 32(7/8), 757-788.

Violeta Domanovic is an assistant professor of educational subject Business Economics, Faculty of Economics, University of Kragujevac, where she got a master's degree in business economics. She held a $\mathrm{PhD}$ in Economics at the University of Belgrade in the field of business economics. Key areas of her scientific interests include performance measurement and management and cost management. 


\title{
EFEKTIVNOST SISTEMA MERENJA PERFORMANSI U USLOVIMA SAVREMENOG POSLOVNOG OKRUŽENJA
}

\author{
Violeta Domanović ${ }^{*}$ \\ Ekonomski fakultet Univerziteta u Kragujevcu
}

Efektivni sistemi merenja performansi neminovno postaju uslov opstanka kompanija u uslovima savremenog dinamičnog i veoma turbulentnog okruženja. Efektivan sistem merenja performansi omogućava kompaniji da meri i kontroliše performanse u skladu sa definisanom strategijom. Pri dizajniranju sistema merenja performansi u savremenom okruženju, uvažavaju se kako finansijski, tako i nefinansijski indikatori koji odražavaju efekte ključnih aktivnosti koje dodaju vrednost jedne kompanije. Uvođenje raznovrsnih strategijski usklađenih indikatora performansi trebalo bi da poboljša organizacione ishode povećavajući kvantum informacija relevantnih za odlučivanje koje su na raspolaganju menadžerima, što olakšava strategijski konzistentno odlučivanje. Efektivnost sistema merenja performansi pod uticajem je brojnih faktora, od kojih su neki predmet istraživanja u radu. Cilj rada jeste da se osvetli značaj primene multidimenzionalnih merila performansi $\mathrm{i}$ konkretnih organizacionih faktora $\mathrm{u}$ procesu primene savremenih sistema merenja performansi.

Ključne reči: merenje performansi, izbalansirana karta rezultata (BSC), multidimenzionalna merila performansi, organizacioni faktori, uloge merenja performansi

\section{UVOD}

Da bi opstale u uslovima savremenog dinamičnog i veoma turbulentnog okruženja, kompanije moraju identifikovati svoje postojeće pozicije, pojasniti svoje ciljeve i delovati na što efektivniji i efikasniji način. Sistemi merenja performansi upravo ovo i omogućavaju. Neely et al, $(1995,81)$ definišu sistem merenja performansi kao "set metrika koji omogućava kvantifikaciju kako efikasnosti tako i efektivnosti

\footnotetext{
* Korespondencija: V. Domanović, Ekonomskifakultet Univerziteta u Kragujevcu, Đ. Pucara 3, 34000 Kragujevac, Srbija; e-mail: vterzic@kg.ac.rs
}

akcija". Efektivan sistem merenja performansi omogućava kompaniji da proceni da li su ciljevi ostvareni i da li je došlo do napretka kompanije u celini (Lebas, 1995), identifikujući poziciju, pojašnjavajući ciljeve i osvetljavajući područja koja treba poboljšati omogućavajući istovremeno pouzdana predviđanja (Neely et al, 1996). Efektivan sistem merenja performansi omogućava kompaniji da meri i kontroliše performanse u skladu sa definisanom strategijom.

Pri dizajniranju sistema merenja performansi $u$ savremenom okruženju, uvažavaju se kako finansijski, tako i nefinansijski indikatori koji odražavaju efekte ključnih aktivnosti koje dodaju vrednost kompanije 
(Kaplan \& Norton, 1996). Uvođenje indikatora u skladu sa definisanom strategijom olakšava strategijsko odlučivanje, a što se u krajnjem odražava na finalne finansijske rezultate kompanije. Inovacije $\mathrm{u}$ sistemu merenja performansi ističu uglavnom ulogu merila performansi u usmeravanju pažnje menadžera na dugoročne posledice svojih akcija tako što ih ohrabruju da prate implementaciju efektivne strategije i da informišu o oceni i razvoju organizacionih sposobnosti (Kaplan \& Norton, 1996; Simons, 2000). Dok neke empirijske studije ukazuju da uvođenje savremenih sistema merenja performansi može rezultirati brojnim boljim krajnjim rezultatima (Davis \& Albright, 2004; Malina \& Selto, 2001), rezultati drugih studija su dvosmisleni (Ittner, Larcker, \& Randall, 2003), a ograničen je uvid u to kako je došlo do ovih poboljšanja.

Sledstveno tome, ovaj rad nastojaće da ispita u kakvoj su vezi primena multidimenionalnih merila performansi i efektivnosti sistema merenja performansi. Organizacioni faktori (podrška top menadžmenta, obuka, učešće zaposlenih, povezanost performansi sa nagradama) značajno utiču na efektivnost primene sistema merenja performansi.

Merenje performansi ima više uloga. Grafton i ostali $(2011,690)$ ističu da "uloga koja omogućava odlučivanje odnosi se na obezbeđenje informacija ex ante donosiocima odluka, $\mathrm{u}$ nameri da se otklone neizvesnosti pri odlučivanju; suprotno, uloga koja utiče na odlučivanje odnosi se na primenu informacija od strane menadžmenta na višem nivou kako bi se ocenile performanse podređenih menadžera". Rad apostrofira vezu između sistema kontrole i performansi. Na osnovu zaključaka studija jednodimenzionalnih, tipično finansijskih merila performansi generirano je shvatanje da informacije o merenju performansi utiču na menadžerske akcije kroz uključivanje istih u mehanizme evaluacije (Sprinkle, 2003). Iako su savremeni sistemi merenja performansi dizajnirani i usvojeni primarno $u$ cilju olakšanja strategijski konzistentnog odlučivanja, a ne za evaluaciju (Kaplan \& Norton, 1996), neosporno je da su informacije o merenju performansi od izuzetnog značaja i u procesima evaluacije (Ferreira \& Otley, 2009).

Imajući u vidu navedeno, predmet istraživanja biće usmeren na ispitivanje potencijalnih efekata primene sistema merenja performansi na krajnje performanse kompanije, kao i potencijalnih faktora koji dovode do takvih efekata. U radu se posebno akcentira dvostruka uloga merenja performansi u procesu odlučivanja. Cilj rada jeste da se ispitaju faktori koji utiču na efektivnost sistema merenja performansi $\mathrm{i}$ da se apostrofira veza između sistema kontrole i krajnjih performansi kompanije. Ključna hipoteza od koje se u radu polazi je da efektivnost i efikasnost primene sistema merenja performansi zavisi od primene multidimenzionalnih merila performansi i konkretnih organizacionih faktora kompanije.

Da bi se testirala polazna hipoteza, primeniće se najpre kvalitativna metodologija, utemeljena na proučavanju i deskriptivnoj analizi istraživačkog problema, a koristiće se i empirijska istraživanja različitih autora iz oblasti računovodstva i poslovne ekonomije i menadžmenta i metodom sinteze i dedukcije, izvršiće se sintetizovanje različitih stavova, na osnovu kojih će se izvesti generalni zaključci vezano za uticaj pojedinih faktora na efektivnost sistema merenja performansi i za ulogu merenja performansi u procesu odlučivanja. Osim toga, na osnovu sprovedenog originalnog empirijskog istraživanja autora, izvešće se konkretni zaključci za Republiku Srbiju.

Polazeći od definisanog predmeta, cilja i polazne hipoteze, $u$ radu će se najpre dati pregled prethodnih istraživanja vezano za efektivnost sistema merenja performansi i za povezanost između multidimenzionalnih merila performansi i konkretnih organizacionih faktora i krajnjih performansi kompanije; zatim, biće reči o metodologiji istraživanja primenjenoj $u$ empirijskim istraživanjima drugih autora i originalnom istraživanju autora, nakon čega će se izvesti relevantni zaključci i ukazati na moguća ograničenja i buduće pravce istraživanja.

\section{PREGLED PRETHODNIH ISTRAŽIVANJA}

\section{Efektivnost sistema merenja performansi}

Sistemi merenja performansi su veoma interesantno polje istraživanja u protekle dve decenije sa različitih aspekata: svrhe i i korisnosti (Simons, 2000), dizajna (Kaplan \& Norton, 1996) i implementacije (Speckbacher 
et al, 2003). "Efektivan sistem merenja performansi pospešuje kongruentnost ciljeva zaposlenih i organizacionih ciljeva, omogućava menadžerima da svoje performanse, kao i performanse zaposlenih, ocenjuju na jedan efektivan i efikasan način" (Tung et al, 2011, 1289), "utiče na individualne performanse preko kognitivnih i motivacionih mehanizama" (Hall, 2011, 68) i olakšava formulisanje budućih strategija i poslovnih aktivnosti i u uslovima sve izraženijeg dinamizma okruženja (Bisbe \& Malagueño, 2012) i sve većeg stepena diversifikacije poslovnih aktivnosti (Micheli et al, 2011).

Savremeno poslovno okruženje, kao izrazito nepredvidivo, dinamično, heterogeno i kompleksno, prosto nameće potrebu za primenom nefinansijskih merila efikasnosti preduzeća, $\mathrm{tj}$. multidimenzionalnih merila. Coram i ostali (2011) ispituju u kojoj meri se finansijski analitičari oslanjaju na nefinansijske indikatore performansi i nalaze asimetrično interesovanje za nefinansijske indikatore $\mathrm{u}$ zavisnosti od trenda interesovanja za finansijske informacije. Ono što je zajedničko svim savremenim sistemima jeste povezivanje strategija, zadataka i merila, kao i uključivanje finansijskih i nefinansijskih merila iz različitih perspektiva. No, bez obzira na to, još uvek su ograničena empirijska istraživanja koja ispituju efektivnost takvih sistema. Najmi i ostali $(2012,1124)$ prezentiraju "jedan konceptualni model za reviziju sistema merenja performansi dizajniranih na osnovu prizme performansi, pri čemu predstavljeni model kategoriše procese revizije $\mathrm{i}$ alate $\mathrm{u}$ dve glavne kategorije: revizija poslovnih performansi i revizija sistema merenja performansi". Štaviše, većina studija ocenjuje efektivnost ovih sistema u odnosu na sveukupne organizacione performanse (Crabtree \& DeBusk, 2008; Davis \& Albright, 2004; Ittner et al, 2003), pretpostavljajući direktnu vezu između sistema merenja performansi i ukupnih performansi kompanije. Krajnje performanse, međutim, kao što su povećanje stope neto rentabilnosti, stope prinosa na ukupni kapital i na vlasnički kapital, neće biti ostvarene ukoliko se konkretni ciljevi ne ostvare (na primer, povećanje prihoda od prodaje, redukcija troškova, motivacija zaposlenih, obezbeđenje povratne sprege i precizne ocene performansi poslovnih jedinica).

Efektivnost primene sistema merenja performansi zavisi od brojnih faktora (Tung et al, 2011). Prvi faktor je primena multidimenzionalnih merila performansi koja bi otklonila ograničenja tradicionalnih sistema i povećala efektivnost istih (Van der Stede et al, 2006; Kaplan \& Norton, 1996). Iako je u literaturi u velikoj meri prihvaćena primena multidimenzionalnih merila performansi, što je rezultiralo brojnim multidimenzionalnim modelima (Van der Stede et al, 2006), postoji značajna varijacija u stopi usvajanja najistaknutijeg multidimenzionalnog pristupa, BSC-a u SAD-u, zemljama nemačkog govornog područja, nordijskim zemljama i u Srbiji (Domanović, 2010, 306310), što dovodi u pitanje vezu između takvih merila i efektivnosti sistema merenja performansi.

Efektivnost sistema merenja performansi iz različitih uglova predmet je interesovanja mnogih autora u novije vreme. Tako, Grafton i ostali (2010) ispituju ulogu merenja performansi i evaluacije $\mathrm{u}$ procesu izgradnje organizacionih sposobnosti i performansi. Pavlov i Bourne (2011) analizirali su efekte merenja performansi na performanse primenom organizacionih rutina kao analitičkih instrumenata $\mathrm{u}$ cilju povezivanja različitih faktora koji utiču na efektivnost merenja performansi u jedan koherentan eksplanatoran model. "Organizacione rutine su zapravo organizacioni procesi koji dovode do organizacionih performansi i konceptualizovane su na dva nivoa - apstraktna ideja o rutini i njen izraz u konkretnoj akciij" (Pavlov \& Bourne, 2011, 112). Lee i Yang $(2011,84)$ ispitivali su "efekat organizacione strukture i konkurencije na dizajn sistema merenja performansi i njihov zajednički uticaj na performanse, ističući da dizajn sistema merenja performansi ima dve dimenzije: primenu integrisanih merila u odnosu na četiri perspektive BSC-a i faze razvoja sistema merenja performansi". Zaključci delimično ukazuju na zajedničke efekte na performanse. Konkretno, što je veći stepen konkurencije, utoliko je značajnija pozitivna korelacija između faza razvoja sistema merenja performansi i performansi i primena integrativnih merila više utiče na organizacione performanse $u$ mehanističkim organizacijama nego $\mathrm{u}$ organskim. Franco-Santos i ostali (2012) detaljno su analizirali posledice primene savremenih sistema merenja performansi u tri kategorije: ponašanje zaposlenih, organizacione sposobnosti i performanse. U kategoriji posledica na ponašanje zaposlenih ističu: strategijski 
fokus, kooperaciju, koordinaciju i participaciju, motivaciju, razumevanje uloge i zadovoljstvo poslom, odlučivanje, učenje i samokontrolu, liderstvo i kulturu, predrasude o subjektivnosti, konflikte i tenzije; u kategoriji posledica na organizacione sposobnosti ističu strategijske procese, komunikaciju, korporativnu kontrolu; $\mathrm{u}$ kategoriji posledica na ukupne performanse ističu performanse na nivou poslovnih jedinica, tima, menadžera i čitavom lancu ponude. "Merenje performansi može stimulisati inicijative zaposlenih da poboljšaju operativne performanse, posebno kada zaposleni učestvuju u razvijanju merila performansi" (Groen et al, 2012, 120). Artz i ostali (2012) ispituju ulogu svojstava merila performansi u procesu dizajniranja sistema merenja performansi i donošenja strategijskih odluka na nivou poslovnih jedinica.

\section{Veza između multidimenzionalnih merila performansi i efektivnosti sistema merenja performansi}

Multidimenzionalni sistemi merenja performansi omogućavaju razmatranje svih relevantnih dimenzija performansi (Ittner et al, 2003). Van der Stede i ostali (2006) nalaze da one organizacije koje, bez obzira na strategiju, imaju ekstenzivnije sisteme merenja performansi, koje uključuju objektivna i subjektivna nefinansijska merila, imaju bolje sveukupne performanse. Van der Stede i ostali (2006), takođe, su demonstrirali su da nefinansijska merila performansi bolja od finansijskih $u$ pogledu implementacije $i$ upravljanja novim inicijativama. Brojna literatura dokazuje da primena multidimenzionalnih sistema doprinosi efektivnosti istih (Tung et al, 2011, Crabtree \& DeBusk, 2008; Davis \& Albright, 2004; Ittner et al, 2003; Malina \& Selto, 2001). Većina ovih studija ispitivala je efektivnost ovih sistema iz perspektiva doprinosa istih finansijskim rezultatima. Primera radi, Domanović (2010) ispituje merenje performansi u kompanijama iz različitih branši kako bi ispitala odnos između implementacije BSC i finansijskih performansi istih. Ova studija podržava teoriju da se BSC može koristiti da bi se poboljšale finansijske performanse. Crabtree i DeBusk (2008) zaključili su da je BSC povezan i sa višim prinosima na akcije. Malina i Selto (2001) ističu da je BSC efektivno sredstvo za ocenu korporativne strategije. Njihovi rezultati takođe pokazuju uzročne relacije između motivacije, strategijske usklađenosti i efektivne menadžment kontrole sa BSC-om.

\section{Veza između organizacionih faktora i efektivnosti sistema merenja performansi}

Kao ključni organizacioni faktori koji utiču na efektivnost sistema merenja performansi najčešce su isticani podrška top menadžmenta (Bourne et al, 2002), obuka, učešće zaposlenih i veza performansi sa nagradama (Burney et al, 2009).

Podrška top menadžmenta značajan je kontingentni faktor koji podržava različite inovacije. Analiziran je uticaj top menadžmenta na efektivnost sistema merenja performansi (Tung et al, 2011; Bourne et al, 2002; Kennerley \& Neely, 2002), ističući da je podrška top menadžmenta kritična za dizajn i implementaciju sistema merenja performansi.

Cavaluzzo i Ittner $(2004,249)$ ističu da je "efektivnost sistema merenja performansi u direktnoj zavisnosti od stepena obuke menadžera". Sva merila performansi treba da se jasno saopštavaju i da su i relevantna i pouzdana tako da menadžeri mogu dobiti korisne informacije za odlučivanje, a zaposleni bolje razumevanje, što će se odraziti na veću posvećenost i efikasnost.

Veće učešće zaposlenih $u$ procesu dizajniranja i implementacije sistema merenja performansi direktno doprinosi njihovoj efektivnosti (Kaplan \& Norton, 2001), zbog kognitivnih mehanizama - bolja komunikacija, primena znanja, razumevanje posla i motivacionih mehanizama - manji otpor promenama, posvećenost sistemu, prihvatanje povratne sprege i ciljeva (Hall, 2011).

Veza performansi i nagrada vitalan je kontingentni faktor u motivisanju zaposlenih i smatra se krucijalnim faktorom efektivnosti sistema (Burney et al, 2009).

\section{Uloga merenja performansi u procesu odlučivanja}

Informacije o merenju performansi olakšavaju proces odlučivanja, identifikovanje problema i predlaganje 
korektivnih mera, signaliziraju kritičke procese i pospešuju organizaciono učenje, a omogućavaju i reviziju planova i strategija (Grafton et al, 2010, Kaplan \& Norton, 1996; Simons, 2000). Merila performansi mogu se koristiti za povratnu (feedback) i anticipativnu (feed-forward), kao i za dijagnostičku i interaktivnu kontrolu (Widener, 2007). U radu se konceptualizuje primena merila performansi u feedback/feed-forward dihotomiji. Pa ipak, usvajanje feedback/feed-forward distinkcije omogućava da se menadžeri organizacionih jedinica usredsrede na distinktivne primene merila performansi pri donošenju individualnih odluka. Tessier i Otley (2012) analiziraju pozitivne i negativne dimenzije kontrole i kao rezultat daju revidirani model koji eksplicitno razdvaja namere menadžera i percepcije zaposlenih o kontroli.

Feedback i feed-forward merila performansi deo su sistema kibernetske kontrole (Grafton et al, 2010, 692). Primarna razlika između njih je $u$ tome što se feedback kontrola fokusira na procenu pravih ishoda, feed-forward kontrola na predviđanje budućih ishoda. "Primena informacija performansi kao mehanizma povratne kontrole pruža menadžerima informacije o ishodima koji ne ispunjavaju očekivanja i deluju kao katalizator identifikacije problema" (Grafton et al, 2010, 692). Ovo stimuliše rešavanje problema, iznalaženje korektivne akcije i organizaciono učenje $\mathrm{u}$ domenu postojeće aktivnosti (Ferreira \& Otley, 2009), a time i fokusiranje menadžera na ostvarenje tekućih ciljeva (Nørreklit, 2000; Simons, 2000). Nørreklit (2000, 81) ističe da procesi kontrole treba da su više interaktivni pri formulisanju strategije, izradi BSC-a i u procesu implementacije iste. Primena merila performansi kao načina signaliziranja budućih ishoda, upoznavanja zaposlenih sa strategijom i ciljeva i kao katalizatora planiranja i postavljanja ciljeva povećava buduće performanse (Kaplan \& Norton, 1996).

Balansiranje sistema kontrole upravljanja omogućava kreiranje dinamičkih tenzija i jedinstvenih organizacionih sposobnosti, pri čemu interaktivna poluga kontrole ima značajnu ulogu u tome (Mundy, 2010). Gond i ostali (2012) analiziraju uticaj sistema kontrole upravljanja na integraciju održivosti u okviru organizacione strategije, na osnovu Simon-ovih poluga kontrole.

\section{METOD ISTRAŽIVANJA}

Rad se oslanja na empirijske analize odnosa između konkretnih organizacionih faktora (podrške top menadžmenta, obuke, učešća zaposlenih i veza performansi sa nagradama) i efektivnosti sistema merenja performansi (Tung et al, 2011), na ispitivanju efekata merenja performansi na performanse (Pavlov \& Bourne, 2011), na pregledu potencijalnih efekata primene savremenih sistema merenja performansi na ponašanje zaposlenih, organizacione sposobnosti i performanse poslovnih jedinica, tima i menadžera (Franco-Santos et al, 2012), na empirijskoj analizi uloga merenja performansi i evaluacije $u$ izgradnji organizacionih sposobnosti i performansi (Grafton et al, 2010), kao i na originalno empirijsko istraživanje autora sprovedeno 2009. godine tokom izrade doktorske disertacije (Domanović, 2010). Predmet istraživanja autora bio je, između ostalog, i uloga BSC-a u procesu unapređenja efikasnosti preduzeća, generalno, sa posebnim osvrtom na mogućnosti i efekte primene BSC-a u kompanijama u Srbiji, za koje je autor pretpostavljao da su menadžeri istih upoznati delimično ili u potpunosti sa BSC-om i koji su delimično ili u potpunosti primenili ovaj model $u$ oceni efikasnosti svojih kompanija. Polazna hipoteza autora bila je da je primena BSC-a je u pozitivnoj korelaciji sa unapređenjem efikasnosti preduzeća.

U empirijskom istraživanju drugih autora, čiji je predmet istraživanja ukratko već objašnjen (Tung et al, 2011; Franco-Santos et al, 2012; Grafton et al, 2010), primenjena je tehnika anketiranja finansijskih direktora na slučajnom uzorku proizvodnih i uslužnih organizacija u Australiji, a u originalnom empirijskom istraživanju autora primenjena je tehnika anketiranja i intervjuisanja finansijskih menadžera i menadžera sektora kontrole $u$ renomiranim odabranim kompanijama u Srbiji. Izabrani su viši finansijski menadžeri i menadžeri sektora kontrole jer se očekivalo da će oni imati bolje razumevanje sistema merenja performansi. Što se tiče uticaja organizacinih faktora na efektivnost sistema merenja performansi iz empirijskih istraživanja pomenutih autora, stopa responzivnosti je 30.9\% (Tung et al, 2011, 1294). Vezano za ulogu merenja performansi, identifikovano je 794 ispitanika menadžera poslovnih jedinica, 188 upitnika je popunjeno i vraćeno (24.58\% responzivnosti), od 
kojih je iskorišćeno 183 sasvim popunjenih upitnika; ispitanici su radili za sadašnjeg poslodavca $u$ proseku od 12 godina (medijana $=10$ godina), imaju $u$ proseku 7.48 godina iskustva (medijana $=5$ godina) $u$ postojećim SPJ i u proseku imaju poziciju rukovodioca 4,17 godina (medijana $=3$ godine); prosečna starost ispitanika je između 40 i 49 godina starosti (Grafton et al, 2010, 695). U originalnom empirijskom istraživanju autora, prikupljeno je i popunjeno direktnim putem šest upitnika od menadžera renomiranih kompanija, a jedan upitnik je nepotpun (Domanović, 2010, 268).

\section{Merenje varijabli}

Efektivnost sistema merena je $\mathrm{u}$ zavisnosti od nivoa $\mathrm{u}$ kojem su željeni ishodi sistema merenja performansi ostvareni. Tung i ostali (2011, 1294-1296) od ispitanika su tražili "da ocene u kojem stepenu je njihov sistem merenja performansi ostvario svaki od željenih ishoda primenom Likertove skale od 5 nivoa, počevši od 1 "ne uopšte" do 5 "u velikom stepenu", pri čemu su ishode podelili u dve dimenzije: sve ono što se odnosi na ostvarenje organizacionih ciljeva i zadataka, te je otuda ova dimenzija označena kao "ishodi vezani za performanse" i sve ono što se odnosi na zaposlene, te je otuda ova dimenzija označena kao "ishodi koji se odnose na osoblje". U ishode performansi ubrajaju se: motivišuće performanse, pomoć u ostvarenju ciljeva, razvijanje performansno orijentisane kulture, podrška promeni, obezbeđenje korisne povratne sprege o performansama, implementacija strategije, precizna ocena poslovanja, obezbeđenje posvećenosti zaposlenih ciljevima, povezivanje individualnih performansi sa performansama poslovnih jedinica, a u ishode osoblja su uključeno je razvijanje individualnih veština i znanja, identifikovanje talentovanih zaposlenih, nagrađivanje talentovanih zaposlenih, identifikovanje zaposlenih sa lošim performansama, upravljanje zaposlenima sa lošim performansama (Tung et al, 2011, 1294-1295). Izračunat je prosečan broj bodova svake dimenzije po svim stavkama, tako da veći (manji) broj bodova reprezentuju bolju (lošiju) efektivnost sistema.

$\mathrm{U}$ oceni stepena primene multidimenzionalnih merila performansi primenjena su dva pristupa: prvo, zahtevalo se od ispitanika da jednostavno označe da li primenjuju BSC ("da" ili "ne") i, drugo, sveobuhvatniji pristup koji se fokusira na merila performansi usvojenih u organizaciji, koji je zahtevao od ispitanika da označe stepen $\mathrm{u}$ kojem koriste različita merila performansi iz različitih perspektiva BSC (Tung et al, 2011, 1295). Ova merila izvedena su uglavnom iz BSC literature i uglavnom su bila dizajnirana za proizvodne organizacije (Van der Stede et al, 2006; Ittner et al, 2003; Kaplan \& Norton, 1996). Faktorska analiza sa presečnom tačkom 0.6 otkrila je 26 stavki u 6 konkretnih dimenzija koje pokrivaju sledeće perspektive: finansije, interni poslovni procesi, učenje i rast i održivost (Tung et al, 2011, 1295). U merila performansi iz finansijske perspektive uključeni su: prihod od prodaje, prinos na investicije, poboljšanje racia neto imovina/obaveze. Iz perspektive kupaca, merila su: isporuka proizvoda na vreme, broj novih kupaca, kvalitet proizvoda, broj vraćenih proizvoda. Iz perspektive internih poslovnih procesa, merila su: utrošci resursa, produktivnost, ciklus rada, troškovi davanja garantnih prava. Iz perspektive učenja i rasta, merila su: časovi obuke, poboljšanje kapaciteta zaposlenih, broj sprovedenih predloga zaposlenih, broj proizvedenih novih proizvoda, vreme komercijalizacije novih proizvoda, procenat od prihoda po osnovu prodaje novih proizvoda. Iz perspektive održivosti, merila su: ulaganja u upravljanje okruženjem, ulaganja u lokalnu zajednicu, usluge povezane sa lokalnom zajednicom. Svaka od ovih pet perspektiva bodovana je kao suma pojedinih stavki u svakoj perspektivi sa većim (manjim) brojem bodova koji ukazuju da se sistem merenja performansi fokusira na svaku perspektivu u većem (manjem) stepenu, a prosečan broj bodova izračunat je kao suma proseka u svim perspektivama, pri čemu veći (manji) broj bodova ukazuje da se multidimenzionalna merila koriste $\mathrm{u}$ većem (manjem) stepenu (Tung et al, 2011, 1295).

Organizacioni faktori relevantni za efektivnost sistema merenja performansi su: podrška top menadžmenta, obuka, učešće zaposlenih, povezanost performansi sa nagradama. Svaki od ova četiri organizaciona faktora meren je primenom sumirane Likertove skale od 5 tačaka počevši od 1 "uopšte se ne slažem" i 5 "veoma se slažem" (Tung et al, 2011, 1295), pri čemu je "podrška top menadžmenta merena primenom sumirane skale, na osnovu izjava ispitanika o tome koliko top 
menadžment obezbeđuje adekvatne resurse, efikasno komunicira sa zaposlenima i svojim autoritetom pruža podršku sistemu merenja performansi (Tung et al, 2011, 1295). Podrška top menadžmenta izmerena je kao prosečan broj bodova, pri čemu veći (manji) broj bodova ukazuje na veću (manju) podršku top menadžmenta. Konkretno, ispitanici su morali da ocene da li je adekvatna obuka zaposlenih da razvijaju, primenjuju i razumeju sisteme merenja performansi, pri čemu je obuka takođe merena kao prosečan broj bodova tako da veći (manji) broj bodova ukazuje na veći (manji) nivo obuke. Osim toga, ispitivalo se $u$ kojoj meri ispitanici učestvuju u dizajniranju sistema merenja performansi i u kojoj meri su uključeni u izbor merila performansi., pri čemu konačan broj bodova predstavlja prosečan broj bodova pojedinih elemenata, pri čemu veći (manji) broj bodova označava veći (manji) stepen učešća zaposlenih (Tung et al, 2011, 1296). U cilju analize efektivnosti sistema merenja performansi, značajno je ispitati koliko savremeni sistemi merenja performansi stimulišu zaposlene da budu što efikasniji $\mathrm{u}$ svom poslu, tj. $\mathrm{u}$ kojem stepenu su performanse povezane sa finansijskim nagradama kao što su isplate ili bonusi, kao i nefinansijskim nagradama kao što su priznanje ili uslužne nagrade.

U originalnom empirijskom istraživanju autora, od ispitanika se zahtevalo da se izjasne da li su upoznati sa savremenim sistemom merenja performansi, da li primenjuju neki savremeni model ili je i dalje zastupljen tradicionalni model merenja performansi, kako bi opisali stanje u procesu implementacije istih, koje perspektive i komponente sadrži BSC, koji tip BSC-a se primenjuje, kakvi su konkretno efekti primene savremenog modela na krajnje rezultate kompanije, SPJ i pojedince (Domanović, 2010, 323-326). Ispitanici su uglavnom dobijali ponuđene odgovore i trebalo je da zaokruže sve ono što se na njih odnosi, mada kod nekih pitanja trebalo je da se dodati nešto van ponuđenih odgovora. Na osnovu odgovora, urađena je deskriptivna statistika koja je dala jednu realnu sliku o efektima i mogućnostima primene BSC-a u Srbiji.

\section{Korišćenje informacija o merenju performansi}

Povratnu i anticipativnu primenu informacija o merenju performansi, Grafton i ostali $(2010,697)$ merili su preko osam pitanja na osnovu postojeće literature
(Ittner, Larcker, \& Randall, 2003; Kaplan \& Norton, 1996; Simons, 2000; Sprinkle, 2003). Od ispitanika (kako u originalnom empirijskom istraživanju autora, tako i $\mathrm{u}$ istraživanju pomenutih autora) se zahtevalo da rangiraju stepen $\mathrm{u}$ kojem oni zapravo primenjuju merila koja olakšavaju odlučivanje "(a) postavljanje ciljeva performansi za poslovne jedinice i/ ili zaposlene na nivou poslovne jedinice; (b) vodič za implementaciju strategije; (c) promocija organizacionog učenja; (d) analiza uticaja prošlih odluka; (e) promptno reispitivanje strategija i meta vrednosti; (f) razvijanje akcionih planova; (g) komuniciranje značajnih aspekata strategije poslovne jedinice; (h) identifikovanje potrebe za korektivnim akcijama" (Domanović, 2010, 323-326; Grafton et al, 2010, 697). Stavke pod a, b, f i g označene su kao anticipativna kontrola, a ostale su označene kao povratna kontrola.

\section{Performanse}

Da bi se stekao uvid u performanse poslovne jedinice, od ispitanika se zahtevalo da ocene performanse tokom protekle godine $\mathrm{u}$ odnosu na konkurente (gde $1=20 \%$ bolje od konkurenata, 7 = 20\% lošje od konkurenata); i sveukupne performanse poslovne jedinice $\mathrm{u}$ odnosu na očekivanja (gde je 1 = loše, 7 = izvanredno) (Grafton et al, 2010, 697). "Faktorska analiza dveju stavki otkriva jedan faktor koji se može označiti kao "performanse" (PERF) i ovaj pojam obuhvata $67 \%$ objašnjene varijacije i Cronbach's Alpha je 0.52, pri čemu se nalazi da je PERF $\mathrm{u}$ značajnoj korelaciji $(\mathrm{r}=0.276, \mathrm{p}<0.01)$ sa merilom koje obuhvata performanse ispitanika $u$ odnosu na konkurente u pogledu: (a) tržišnog učešća; (b) profita; (c) stope rasta prihoda od prodaje, što demonstrira kriterijum validnosti" (Grafton et al, 2010, 697-698).

\section{REZULTATI}

Tabela 1 pokazuje sumarnu deskriptivnu statistiku za zavisne i nezavisne varijable.

Srednja vrednost bodova o efektivnosti sistema merenja performansi za ishode koji se odnose na performanse i za ishode koji se odnose na zaposlene je nešto viša od srednje vrednosti $u$ intervalu, što 
Tabela 1 Deskriptivna statistika

\begin{tabular}{lcccccc}
\hline Varijable & $\begin{array}{c}\text { Broj ispi- } \\
\text { tanika }\end{array}$ & $\begin{array}{c}\text { Aritm. sre- } \\
\text { dina }\end{array}$ & $\begin{array}{c}\text { Stand. devi- } \\
\text { jacija }\end{array}$ & $\begin{array}{c}\text { Minimum } \\
\text { (teorijski) }\end{array}$ & $\begin{array}{c}\text { Maksimum } \\
\text { (teorijski) }\end{array}$ & Cronbach $\alpha$ \\
\hline Nezavisne & & & & & & \\
$\begin{array}{l}\text { Primena multidimenzionalnih } \\
\text { merila performansi }\end{array}$ & 118 & 2.94 & 0.70 & $1.17(1)$ & $4.67(5)$ & \\
$\begin{array}{l}\text { Podř̌ka top menadžmenta } \\
\text { Obuka }\end{array}$ & 117 & 3.51 & 1.02 & $1(1)$ & $5(5)$ & 0.915 \\
Učešće zaposlenih & 117 & 3.11 & 1.07 & $1(1)$ & $5(5)$ & 0.963 \\
$\begin{array}{l}\text { Veza performansi i finansijskih } \\
\text { nagrada }\end{array}$ & 117 & 2.41 & 1.02 & $1(1)$ & $5(5)$ & 0.761 \\
$\begin{array}{l}\text { Veza performansi i nefinansijskih } \\
\text { nagrada }\end{array}$ & 117 & 3.50 & 1.16 & $1.00(1)$ & $5.00(5)$ & \\
\hline $\begin{array}{l}\text { Zavisne varijable } \\
\text { Efektivnost sistema merenja per- }\end{array}$ & 117 & 2.93 & 1.13 & $1.00(1)$ & $5.00(5)$ & \\
formansi (ishodi performansi) & 117 & 3.50 & 0.81 & $1(1)$ & $5(5)$ & 0.932 \\
Efektivnost sistema (ishodi osoblja) & 117 & 3.26 & 0.93 & $1(1)$ & $5(5)$ & 0.924 \\
\hline
\end{tabular}

Izvor: Tung et al, 2011

pokazuje da su ispitanici svoje sisteme merenja performanse ocenili umereno efektivnim. Ishodi koji se odnose na performanse ostvareni su u većem stepenu, sa srednjom vrednošću bodova svih stavki jednakom ili većom od ishoda koji se odnose na osoblje. Ishodi koji se odnose na performanse i koji su ostvareni $u$ najvećem stepenu su: pomoć u ostvarenju ciljeva; obezbeđenje povratne informacije o performansama zaposlenima; razvijanje performansno orijentisane kulture i obezbeđenje tačne procene performansi poslovnih jedinica. Ishodi koji se odnose na osoblje i koji su ostvareni u najvećem stepenu uključili su: razvijanje individualnih veština i znanja, identifikovanje talentovanih zaposlenih i nagrađivanje talentovanih zaposlenih. Što se tiče organizacionih faktora, srednja vrednost povezanosti performansi i nefinansijskih nagrada je ispod središne tačke $u$ intervalu i ukazuje na relativno slabu povezanost između performansi i nefinansijskih nagrada.

Što se tiče primene multidimenzionalnih merila performansi, istraživanje (Tung et al, 2011, 1297) je takođe pokazalo da "39 ispitanika (33.1\%) je izjavilo da primenjuje BSC u svojim poslovnim jedinicama, pri čemu se jedan sveobuhvatniji pristup merenju primene multidimenzionalnih merila performansi fokusirao na stepen primene 26 merila performansi iz pet perspektiva BSC, sa srednjom vrednošću primene multidimenzionalnih merila ispod središne vrednosti intervala, a što ukazuje na umerenu primenu multidimenzionalnih merila u proizvodnim organizacijama".

Kao što se može videti iz Tabele 2, najveći naglasak je na finansijskoj perspektivi (3.59), zatim na kupce (3.43),

Tabela 2 Primena multidimenzionalnih merila performansi

\begin{tabular}{lcc}
\hline BSC perspektive & $\begin{array}{c}\text { Aritmetička } \\
\text { sredina }\end{array}$ & Rang \\
\hline Finansije & 3.59 & 1 \\
Kupci & 3.43 & 2 \\
Interni poslovni procesi & 3.06 & 3 \\
Učenje i rast & 3.11 & 4 \\
Održivost & 2.19 & 5 \\
\hline
\end{tabular}

Izvor: Autor, na osnovu Tung et al, 2011 
učenje i rast (3.11) i interne poslovne procese (3.06). Srednja vrednost održivosti (2.19) ispod je središne vrednosti intervala što ukazuju na slabu primenu ove perspektive.

Što se tiče Republike Srbije (Domanović, 2010), menadžeri uglavnom nisu bili upoznati sa BSC ili delimično upoznati. Istina, pojedini menadžeri primenjuju BSC, a i nisu svesni da je to BSC. Najveći naglasak je i dalje (Tabela 3) na finansijskoj perspektivi, zatim na kupce, učenje i rast i interni poslovni procesi.

Tabela 3 Primena multidimenzionalnih merila performansi u Republici Srbiji

\begin{tabular}{lc}
\hline BSC perspektive & Broj kompanija \\
\hline Finansije & 5 \\
Kupci & 5 \\
Interni poslovni procesi & 3 \\
Učenje i rast & 4 \\
Ostalo & 1 \\
\hline
\end{tabular}

Izvor: Autor

Rezultati sprovedenog istraživanja autora ukazali su da su menadžeri mnogih kompanija u svetu skeptični u pogledu krajnjih efekata primene BSC-a na efikasnost preduzeća. Menadžeri kompanija u zemljama nemačkog govornog područja BSC vide kao instrument upravljanja vrednošću za akcionare. BSC je dosta zastupljen u nordijskim zemljama, doprinoseći najviše logistici, pouzdanosti isporuke i skladištenju, kao nefinansijskim indikatorima efikasnosti. U Srbiji, dosledna primena BSC-a karakteristična je za ona preduzeća koja su pod uplivom inostranog kapitala. Ekonomski efekti primene BSC-a su: sistematičnija analiza parametra efikasnosti, poređenje troškova i efikasnija realizacija strategije na nivou poslovnih jedinica, a za pojedince pomoć $u$ obavljanju radnih zadataka, ukazuje ne neke eventualne nedostatke procesa, nezadovoljstvo zaposlenih i omogućava preduzimanje korektivnih mera, a i varijabilni deo zaposlenih, pre svega menadžera delimično zavisi i od ispunjenja plana, $\mathrm{tj}$. ciljnih vrednosti parametra $\mathrm{u}$ BSC-u.

\section{Analiza primene multidimenzionalnih merila i organizacionih faktora na efektivnost sistema merenja performansi}

Tabela 4 prikazuje rezultate jednosmerne analize varijacije (ANOVA), koja ispituje razliku u nivou efektivnosti sistema u zavisnosti od toga da li ispitanici primenjuju BSC ili ne. Rezultati pokazuju da ispitanici koji su primenili BSC imali su značajno viši nivo efektivnosti kako u pogledu ishoda performansi tako i ishoda koji se odnose na osoblje.

Ovakvi rezultati daju preliminarni dokaz da je primena multidimenzionalnih merila performansi povezana sa efektivnošću sistema, što potvrđuje polaznu hipotezu. Veza između multidimenzionalnih merila i efektivnosti takođe je analizirana pomoću još sveobuhvatnijeg pristupa na osnovu stepena primene multidimenzionalnih merila. Postupna regresija (korak po korak regresija) je primenjena da bi se ispitala veza između primene multidimenzionalnih merila i organizacionih faktora sa efektivnošću sistema na osnovu odgovora 115 ispitanika (Tabela 5).

Rezultati $\mathrm{u}$ tabeli 5 pokazuju da na ishode koji se odnose na performanse, model je bio veoma statistički značajan (F 1/4 63.812, p $1 / 4$ 0.000) sa koeficijentom determinacije 0.530 , što ukazuje da se $53 \%$ varijacija $\mathrm{u}$ ostvarenju ishoda koji se odnose na performanse može objasniti eksplanatornim faktorima. Ovaj model otkriva da primena multidimenzionalnih merila

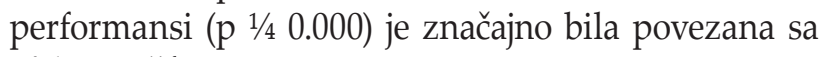
efektivnošću sistema.

Osim toga, podrška top menadžmenta ( $\left.\begin{array}{lll}1 / 4 & 0.000\end{array}\right)$ značajno je bila povezana sa ishodima koji se odnose na performanse. Što se tiče ishoda vezanih za osoblje, sa koeficijentom determinacije 0.405 , znači da se $40.5 \%$ varijacija u ostvarenju ishoda vezanih za osoblje može objasniti eksplanatornim faktorima.

Dakle, primena multidimenzionalnih merila performansi značajno je povezana sa ostvarenjem ishoda vezanih za osoblje i nivo obuke takođe je značajno povezan sa efektivnošću sistema merenja performansi. Ovakvi zaključci daju dalju podršku polaznoj hipotezi. Značaj primene multidimenzionalnih merila performansi u objašnjenju nivoa efektivnosti sistema merenja performansi naveo je na dalju analizu kako bi se ispitala povezanost između perspektiva BSC i efektivnosti sistema. 
Tabela 4 Rezultati jednosmerne analize varijacije (ANOVA)

\begin{tabular}{|c|c|c|c|c|c|c|c|}
\hline \multirow[b]{2}{*}{ Primena BSC } & \multirow{2}{*}{$\begin{array}{c}\text { Broj ispi- } \\
\text { tanika }\end{array}$} & \multicolumn{3}{|c|}{ Ishodi performansi } & \multicolumn{3}{|c|}{ Ishodi osoblja } \\
\hline & & $\begin{array}{l}\text { Aritm. sre- } \\
\text { dina }\end{array}$ & F statistika & Značaj & $\begin{array}{l}\text { Aritm. sre- } \\
\text { dina }\end{array}$ & F statistika & Značaj \\
\hline Korisnici & 39 & 3.88 & 14.297 & 0.000 & 3.71 & 15.869 & 0.000 \\
\hline Nekorisnici & 78 & 3.31 & & & 3.03 & & \\
\hline
\end{tabular}

Izvor: Tung et al, 2011

Tabela 5 Rezultati postupne regresione analize

\begin{tabular}{|c|c|c|c|c|c|c|}
\hline \multirow{2}{*}{ Varijable } & \multicolumn{3}{|c|}{ Ishodi performansi } & \multicolumn{3}{|c|}{ Ishodi osoblja } \\
\hline & Koeficijent & t statistika & Značaj & Koeficijent & t statistika & Značaj \\
\hline $\begin{array}{l}\text { Multidimenzionalni } \\
\text { sistemi }\end{array}$ & 0.343 & 4.512 & 0.000 & 0.374 & 4.465 & 0.000 \\
\hline $\begin{array}{l}\text { Podrška top } \\
\text { menadžmenta }\end{array}$ & 0.487 & 6.411 & 0.000 & & & \\
\hline Obuka & & & & 0.362 & 4.325 & 0.000 \\
\hline F vrednost & 63.812 & & & 38.535 & & \\
\hline P vrednost & 0.000 & & & 0.000 & & \\
\hline $\begin{array}{l}\text { Koeficijent determi- } \\
\text { nacije }\end{array}$ & 0.530 & & & 0.405 & & \\
\hline $\begin{array}{l}\text { Prilagođeni koeficijent } \\
\text { determinacije }\end{array}$ & 0.522 & & & 0.395 & & \\
\hline Broj ispitanika & 115 & & & 115 & & \\
\hline
\end{tabular}

Izvor: Autor, na osnovu Tung et al, 2011

\section{Analiza povezanosti perspektiva BSC i efektivnosti sistema merenja performansi}

Postupnom regresionom analizom došlo se do sledećih zaključaka da su ishodi vezani za performanse statistički su značajni sa koeficijentom determinacije 0.528 , što ukazuje da $52.8 \%$ varijacija u ostvarenju ishoda vezanih za performanse može se objasniti dvema perspektivama BSC koje su značajno povezane sa ishodima vezanim za performanse: interni poslovni procesi i učenje i rast. Ishodi koji se odnose na osoblje takođe su statistički značajni sa koeficijentom determinacije 0.499 , što ukazuje da $49.9 \%$ varijansi u ostvarenju ishoda vezanih za osoblje može se objasniti dvema perspektivama BSC koje su značajno povezane sa ishodima vezanim za osoblje: učenje i rast i održivost.
U Srbiji, ishodi koji se odnose na performanse značajno se mogu objasniti finansijskom perspektivom i perspektivom kupaca $(100 \%)$, a ishodi koji se odnose na osoblje moguće je objasniti perspektivom internih poslovnih procesa $(60 \%)$ i učenja i rasta zaposlenih $(80 \%)$.

\section{ZAKLJUČAK}

Efektivnost sistema merenja performansi može se posmatrati kroz dve dimenzije i to preko ishoda povezanih sa performansama kompanije i ishoda povezanih sa zaposlenima. Faktorskom analizom utvrđeno je da je srednja vrednost obe dimenzije bila iznad središne vrednosti intervala, što ukazuje da 
je efektivnost sistema umereno efektivna. Ovakav zaključak osvetljava značaj ispitivanja kontingentnih faktora koji utiču na efektivnost sistema. Rezultati su takođe pokazali da je veći uspeh ostvaren u ishodima orijentisanim na performanse nego na osoblje. Ovo ukazuje da sistemi merenja performansi treba da se uglavnom koriste kao alat upravljanja u cilju motivacije, implementacije strategije i ostvarenja ciljeva, tj. kao instrumentarijum strategijske kontrole i kontrole upravljanja.

Manji akcenat je stavljen na ostvarenje ishoda povezanih sa osobljem kao što su briga za zaposlene, efikasno korišćenje vremena, upravljanje zaposlenima koji ostvaruju lošije rezultate. Poslednji zaključak tiče se opstanka kompanije u promenljivom okruženju, koji zavisi i od jednih i drugih ishoda. Otuda, organizacije koje $\mathrm{u}$ zaposlenima vide potencijalne partnere i značajnu aktivu povećavaju verovatnoću ostvarenja boljih organizacionih performansi. Postoji takođe dokaz da ishodi osoblja mogu biti od pomoći pri ostvarenju ishoda performansi. Ukoliko se organizacije posvete problemima zaposlenih na pravi način, oni će više biti emotivno vezani za organizaciju i otuda voljniji da ostvare organizacione ciljeve.

Sveobuhvatnija analiza primene multidimenzionalnih merila performansi otkrila je da su proizvodne kompanije najveći akcenat stavile na merila koja se odnose na finansijsku perspektivu BSC, zatim na kupce, učenje i rast, interne poslovni procese i održivost. Analiza odnosa između primene multidimenzionalnih merila performansi i organizacionih faktora sa efektivnošću otkrila je da primena ovih merila, kao što je operacionalizovano $u$ BSC, zajedno sa organizacionim faktorima (podrškom top menadžmenta i obukom) značajno je povezana sa efektivnošću.

Analiza veze između organizacionih faktora i efektivnosti sistema daje uvid u preovlađujuće organizacione uslove koji bi mogli da povećaju/ugroze efektivnost. Podrška top menadžmenta je povezana sa ishodima performansi, a nivo obuke sa ishodima osoblja. Otuda, u nameri da se ostvare željeni ishodi performansi, potreban je koncentrisani napor top menadžmenta usmeren ka kontinuelnom poboljšanju, otvorenoj komunikaciji i konzistentna podrška.
Otuda se top menadžment ohrabruje da se lično posveti sistemima merenja performansi i osigura da je dovoljno vremena i resursa posvećeno svrsishodnom razvijanju i upravljanju postojećim sistemima. Osim toga, organizacije koje obezbeđuju bolju obuku osoblja u stanju su da ostvare željene ishode osoblja. Dve dimenzije efektivnosti sistema, ishodi performansi i osoblja, služe da bi menadžment bio svestan potrebe da se fokusira na različite aspekte efektivnosti sistema, kao i da bi se istraživačima pružilo novo merilo za procenu efektivnosti. Osim toga, povezanost multidimenzionalnih merila performansi i organizacionih faktora sa efektivnošću sistema pruža menadžerima uvid $u$ željene karakteristike efektivnog sistema i u preovlađujuće organizacione uslove koji podržavaju sisteme. Otuda, menadžeri treba da se fokusiraju na primenu multidimenzionalnih merila i da povećavaju podršku top menadžmenta kao i obuke $\mathrm{u}$ odnosu na sisteme merenja performansi.

Ovo istraživanje podložno je uobičajenim ograničenjima anketnog istraživanja i prikupljanja podataka iz sekundarnih izvora. S obzirom da je anketiranje korisno $\mathrm{u}$ utvrđivanju povezanosti a ne uzročnih odnosa između varijabli, ovakav pristup generira potencijalne pretnje vezano za odgovore ispitanika. Ovo važi i za istraživanje autora, pored toga što je veličina uzorka bila mala i nedovoljna za neku ozbiljniju statističku analizu. Ubuduće, potrebno je povećati veličinu uzorka i razmatrati vezu između drugih organizacionih faktora kao što su, na primer, organizaciona struktura, stil menadžmenta, međuljudski odnosi sa efektivnošću sistema. Da bi se povećala uopštenost zaključaka, buduće studije mogle bi biti sprovedene primenom sličnih parametara $\mathrm{u}$ drugim delatnostima kao što su usluge i neprofitni sektor.

Ubuduće, može se dalje istraživati na koji sve način merenje performanse utiče na donošenje odluka, posebno u situacijama gde su uloge potencijalno konfliktne umesto da se međusobno pojačavaju. Bilo bi interesantno ispitati u kojem se stepenu interakcija među ulogama merenja performansi manje ili više fokusira na finansijska merila, kao i to kako se ove interakcije odražavaju na konkretne individualne odluke. 


\section{ZAHVALNICA}

Ovaj rad je deo interdisciplinarnog istraživačkog Projekta (br. 41010), koji finansira Ministarstvo nauke Republike Srbije

\section{REFERENCE}

Adler, R. (2011). Performance management and organizational strategy: how to design systems that meet the needs of confrontation strategy firms. The British Accounting Review, $43,251-263$

Artz, M., Homburg, C., \& Rajab, T. (2012). Performancemeasurement system design and functional strategic decision influence: the role of performance-measure properties. Accounting, Organizations and Society, 37, 445-460.

Baird, K., Harrison, G., \& Reeve, R. (2007). Success of activity management practices: the influence of organizational and cultural factors. Accounting and Finance, 47(1), 47-67.

Bisbe, J., \& Malagueño, R. (2012). Using strategic performance measurement systems for strategy formulation: does it work in dynamic environments? Management Accounting Research, 23, 296-311.

Bourne, M. C., Neely, A. D., Platts, K. W., \& Mills, J. F. (2002). The success and failure of performance measurement initiatives: the perceptions of participating managers. International Journal of Operations and Production Management, 22(11), 1288-1310.

Burney, L. L., Henle, C. A., \& Widener, S. K. (2009). A path model examining the relations among strategic performance measurement system characteristics, organizational justice, and extra- and in-role performance. Accounting, Organizations and Society, 34(3/4), 305-321.

Cavaluzzo, S. K., \& Ittner, C. D. (2004). Implementing performance measurement innovations: evidence from government. Accounting, Organisations and Society, 29(1), 243267.

Chenhall, R. H. (2003). Management control systems design within its organizational context: findings from contingency-based research and directions for the future. Accounting, Organizations and Society, 28(2/3), 141-163.

Coram, J. P., Mock, J. T., \& Monroe, S. G. (2011). Financial analysts' evaluation of enhanced disclosure of non-financial performance indicators. The British Accounting Review, 43, 87101.
Crabtree, A. D., \& DeBusk, G. K. (2008). The effects of adopting the balanced scorecard on shareholder returns. Advances in Accounting, 24(1), 8-15.

Davis, S., \& Albright, T. (2004). An investigation of the effect of balanced scorecard implementation on financial performance. Management Accounting Research, 15(2), 135153.

Domanović, V. (2010). Balanced Scorecard - mogućnosti i efekti primene. Kragujevac: Ekonomski fakultet Univerziteta $\mathrm{u}$ Kragujevcu.

Ferreira, A., \& Otley, D. (2009). The design and use of performance management systems: An extended framework for analysis. Management Accounting Research, 20(4), 263-282.

Franco-Santos, M., Lucianetti, L., \& Bourne, M. (2012). Contemporary performance measurement systems: a review of their consequences and a framework for research. Management Accounting Research, 23, 79-119.

Gond, J.-P., Grubnic, S., Herzig, C., \& Moon, J. (2012). Configuring management control systems: theorizing the integration of strategy and sustainability. Management Accounting Research, 23, 205-223.

Grafton, J., Lillis, M. A., \& Widener, K. S. (2010). The role of performance measurement and evaluation in building organizational capabilities and performance. Accounting, Organizations and Society, 35, 689-706.

Groen, B. A. C., Wouters, M. J. F., \& Wilderom, C. P. M. (2012). Why do employees take more initiatives to improve their performance after co-developing performance measures? A Field study. Management Accounting Research, 23, 120-141.

Hall, M. (2011). Do comprehensive performance measurement systems help or hinder managers' mental model development? Management Accounting Research, 22, 68-83.

Ittner, C. D., Larcker, D. F., \& Randall, T. (2003a). Performance implications of strategic performance measurement in financial services firms. Accounting, Organizations and Society, 28(7/8), 715-41.

Ittner, C. D., Larcker, D. F., \& Meyer, M. W. (2003b). Subjectivity and the weighting of performance measures: evidence from a balanced scorecard. The Accounting Reivew, 78(3), 725-758.

Kaplan, R. S., \& Norton, D. P. (1996). Linking the balanced scorecard to strategy. California Management Review, 39(1), $53-79$.

Kaplan, R. S., \& Norton, D. P. (2001). The Strategy-focused Organization: How Balanced Scorecard Companies Thrive in the New Business Environment. Boston: Harvard Business School Press. 
Kennerley, M., \& Neely, A. (2002). A framework of the factors affecting the evolution of performance measurement systems. International Journal of Operations and Production Management, 22(11), 1222-1245.

Lebas, M. J. (1995). Performance measurement and performance management. International Journal of Production Economics, 41(1-3), 23-35.

Lee, C.-L., \& Yang, H.-J. (2011). Organization structure, competition and performance measurement systems and their joint effects on performance. Management Accounting Research, 22, 84-104.

Malina, M. A., \& Selto, F. H. (2001). Communicating and controlling strategy: an empirical study of the effectiveness of the balanced scorecard. Journal of Management Accounting Research, 13, 47-90.

Micheli, P., Mura, M., \& Agliati, M. (2011). Exploring the roles of performance measurement systems in strategy implementation: the case of a highly diversified group of firms. International Journal of Operations \& Production Management, 31(10), 1115-1139.

Mundy, J. (2010). Creating dynamic tensions through a balanced use of management control systems. Accounting, Organizations and Soceity, 35, 499-523.

Najmi, M., Etebari, M., \& Emami, S. (2012). A framework to review performance prism. International Journal of Operations E Production Management, 32(10), 1124-1146.

Neely, A. (1999). The performance measurement revolution: why now and what next? International Journal of Operations and Production Management, 19(2), 205-228.

Neely, A., Gregory, M., \& Platts, K. (1995). Performance measurement system design: a literature review and research agenda. International Journal of Operations and Production Management, 25(12), 80-116.
Neely, A., Mills, J., Platts, K., Gregory, M., \& Richards, H. (1996). Performance measurement system design: should process based approaches be adopted? International Journal of Production Economics, 46, 423-431.

Nørreklit, H. (2000). The balance on the balanced scorecard a critical analysis of some of its assumptions. Management Accounting Research, 11(1), 65-88.

Pavlov, A., \& Bourne, M. (2011). Explaining the effects of performance measurement on performance - an organizational routines perspectives. International Journal of Operations \& Production Management, 31(1), 101-122.

Simons, R. (2000). Performance Measurement and Control Systems for Implementing Strategy. NJ: Prentice-Hall, Englewood Cliffs.

Speckbacher, G., Bischof, J., \& Pfeiffer, T. (2003). A descriptive analysis on the implementation of balanced scorecard in German speaking countries. Management Accounting Research, 14(4), 361-388.

Sprinkle, G. B. (2003). Perspectives on experimental research in managerial accounting. Accounting, Organizations and Society, 28(2-3), 287-318.

Tessier, S., \& Otley, D. (2012). A conceptual development of Simons' levers of control framework. Management Accounting Research, 23, 171-185.

Tung, A., Baird, K., \& Schoch, P. H. (2011). Factors influencing the effectiveness of performance measurement systems. International Journal of Operations \& Production Management, 31(12), 1287-1310.

Van der Stede, W. A., Chow, C. W., \& Lin, T. W. (2006). Strategy, choice of performance measures, and performance. Behavioral Research in Accounting, 18, 185-205.

Widener, S. K. (2007). An empirical analysis of the levers of control framework. Accounting, Organizations and Society, 32(7/8), 757-788.

Violeta Domanović je docent na nastavnom predmetu Ekonomika preduzeća, na Ekonomskom fakultetu Univerziteta u Kragujevcu. Doktorirala je na Ekonomskom fakultetu Univerziteta u Beogradu iz oblasti poslovne ekonomije. Ključne oblasti njenog naučnog istraživanja su merenje i upravljanje performansama preduzeća. 


\title{
THE EFFECTIVENESS OF THE PERFORMANCE MEASUREMENT IN TERMS OF CONTEMPORARY BUSINESS ENVIRONMENT
}

\author{
Violeta Domanovic \\ Faculty of Economics, University of Kragujevac, Kragujevac, Serbia
}

\begin{abstract}
The effective performance measurement systems inevitably become the condition of companies' existence in terms of contemporary dynamic and very turbulent environment. The effective performance measurement system enables company to measure and control performance in accordance with the defined strategy. In designing of the performance measurement system in contemporary environment, there should be respected financial as well as non-financial indicators reflecting the effects of the key activities, which add the value of any company. Introduction of the diversified strategic aligned performance indicators should improve the organizational outcomes by increasing the quantity of the information relevant for making decision, which are at managers disposal, what strategic consistent making decision makes ease. The effectiveness of the performance measurement system is influenced by numerous factors, some of which are the subject of the paper. The aim of the paper is to highlight the significance of multidimensional measures use as well as of the specific organizational factors in the process of contemporary performance measurement systems implementationi.
\end{abstract}

Keywords: performance measurement, balanced scorecard (BSC), multidimensional performance measures use, organizational factors, performance measurement role

JEL Classification: M21, M41 